\title{
Gene Expression of Prohormone and Proprotein Convertases in the Rat CNS: A Comparative in situ Hybridization Analysis
}

\author{
Martin K.-H. Schafer, ${ }^{1, a}$ Robert Day, ${ }^{2}$ William E. Cullinan, ${ }^{1}$ Michel Chrétien, ${ }^{3}$ Nabil G. Seidah, ${ }^{2}$ and Stanley J. \\ Watson ${ }^{1}$ \\ 'Mental Health Research Institute, University of Michigan, Ann Arbor, Michigan 48109-0720 and J. A. DeSeve Laboratory \\ of ${ }^{2}$ Biochemical and ${ }^{3}$ Molecular Neuroendocrinology, Clinical Research Institute of Montreal, Montreal, Quebec, Canada \\ $\mathrm{H} 2 \mathrm{~W} 1 \mathrm{R} 7$
}

\begin{abstract}
Posttranslational processing of proproteins and prohormones is an essential step in the formation of bioactive peptides, which is of particular importance in the nervous system. Following a long search for the enzymes responsible for protein precursor cleavage, a family of Kexin/subtilisinlike convertases known as PC1, PC2, and furin have recently been characterized in mammalian species. Their presence in endocrine and neuroendocrine tissues has been demonstrated. This study examines the mRNA distribution of these convertases in the rat CNS and compares their expression with the previously characterized processing enzymes carboxypeptldase E (CPE) and peptidylglycine $\alpha$-amidating monooxygenase (PAM) using in situ hybridization histochemistry. Furin mRNA was ubiquitously distributed and detected both in neurons and non-neuronal tissue throughout the brain with a higher abundance in ependyma, the circumventricular organs, the islands of Calleja, hippocampus, and allocortex. The cellular localization of PC1 and PC2 was exclusively neuronal with highest concentrations in known neuropeptide-rich brain regions. In general, PC2 was more widely expressed than PC1 in the CNS, although many regional variations were detected. The identification of specific combinations of convertase expression together with CPE and PAM expression in neuropeptide-rich brain regions suggests that specific enzymatic pathways are involved in neuropeptide precursor processing, and that these specific combinations are responsible for region-specific differences of posttranslational processing.
\end{abstract}

[Key words: prohormone convertase 1, prohormone convertase 2, furin, carboxypeptidase E, peptidylglycine $\alpha$-amidating monooxygenase, KEX 2, mRNA, neuropeptide, CNS]

Received June 23, 1992; revised Sept. 22, 1992; accepted Sept. 30, 1992.

We acknowledge the excellent technical assistance of Sharon Burke. We express our gratitude to Dr. E. Eipper (Baltimore) for her generous gift of a PAM cDNA clone. M.K.-H.S. and R.D. have equally contributed to this study. This work was supported by research grants from NIDA (RO1 DA00265-12) and NIMH (MH42251-06) to S.J.W., and from the Medical Research Council (MRC) of Canada, MT-11268 to R.D., PG2 to N.G.S. and M.C., and the J. A. DeSève Succession to M.C. R.D. is a scholar of the Fonds de la Recherche en Santé du Québec (FRSQ).

Correspondence should be addressed to Dr. Robert Day, J. A. DeSève Laboratory of Biochemical Neuroendocrinology, Clinical Research Institute of Montreal, 110 Pine Avenue West, Montreal, Quebec, Canada H2W 1R7.

"Present address: Anatomisches Institut, Johannes Gutenberg-Universität, 6500 Mainz, Germany.

Copyright (c) 1993 Society for Neuroscience $0270-6474 / 93 / 131258-22 \$ 05.00 / 0$
The participation of neuropeptides in the modulation of a variety of CNS functions is well established. Many neuropeptides are synthesized as inactive precursor proteins, which undergo an enzymatic cascade of posttranslational processing and modification events during their intracellular transport before the final bioactive products are secreted and act at either pre- or postsynaptic receptors. Initial endoprotenlytic cleavage occurs C-terminal to pairs of basic amino acids such as lysine-arginine (Docherty and Steiner, 1982), and is followed by the removal of the basic residues by exopeptidases. Further modifications can occur in the form of $\mathrm{N}$-terminal acetylation or C-terminal amidation, which is essential for the bioactivity of many neuropeptides. Recent success in the molecular characterization of these enzymes has provided us with the necessary tools to investigate the regulation of neuropeptide expression at the level of the enzymes involved in proneuropeptide processing. The primary amino acid sequence of two postcleavage modification enzymes, carboxypeptidase E (CPE) (Fricker et al., 1989) and peptidylglycine $\alpha$-amidating monooxygenase (PAM) (Eipper et al., 1987), have been characterized by cDNA cloning, and their brain distribution (Macumber et al., 1990; Schäfer et al., 1992), tissue-specific expression, and regulation have been reported (Bondy et al., 1989; Braas et al., 1989; Grimwood et al., 1989; Ouafik et al., 1989; Thiele et al., 1989; Fricker et al., 1990a,b; Hook et al., 1990). More recently, the identification of endoproteolytic enzymes has been advanced by the cloning of the yeast enzyme Kexin and the demonstration of its ability to process mammalian protein precursors both in vitro and in vivo (Mizuno et al., 1988; Thomas et al., 1988; Fuller et al., 1989; Zollinger et al., 1990; Foster et al., 1991). Finally, the long search for the homologous mammalian proteinases led to the discovery of three distinct proteins belonging to the class of Kexin/subtilisin-like enzymes, namely, furin (Roebroek et al., 1986; Fuller et al., 1989; van den Ouweland, 1990), PC1 (Seidah et al., 1990, 1991), also known as PC3 (Smeekens et al., 1991), and PC2 (Seidah et al., 1990; Smeekens and Steiner, 1990).

Furin, the product of the fur gene (also known as PACE (Wisc et al., 1990), has been shown in cellular cotransfection experiments to cleave efficiently the protein precursors of von Willebrand factor, NGF, complement $\mathrm{C} 3$, and proalbumin (Bresnahan et al., 1990; Van de Ven et al., 1990; Wise et al., 1990; Misumi et al., 1991). The ubiquitous distribution of furin mRNA, which is present in most tissues and cell lines (Schalken et al., 1987; Bresnahan et al., 1990; Hatsuzawa et al., 1990), suggests that furin has a wider spectrum of action than just the specific 
processing of proneuropeptides, which are highly concentratcd in neuronal and endocrine tissues.

The application of PCR-assisted cDNA cloning led to the discovery of two more subtilisin-like enzymes, the prohormone convertases PCl (Seidah et al., 1990, 1991; Smeekens et al., 1991) and PC2 (Seidah et al., 1990; Smeekens and Steiner, 1990). In situ hybridization analysis revealed their tissue-specific distribution, and as expected for putative prohormone cleavage enzymes, a high mRNA concentration was found in mouse neuronal and endocrine tissues (Seidah et al., 1990, 1991). Cotransfection experiments not only demonstrated their capacity to process correctly the prohormones proopiomelanocortin (POMC) (Benjannet et al., 1991; Thomas et al., 1991) and prorenin (Benjannet et al., 1992), but also showed their distinct cleavage specificities. For example, in the pituitary anterior lobe, POMC is processed by $\mathrm{PCl}$ into ACTH and $\beta$-lipotropin, and in the corticotrophs PC1 is the more abundant enzyme (Day et al., 1992). However, in the intermediate lobe POMC is processed into $\alpha$-melanocyte stimulating hormone ( $\alpha$-MSH), and in this tissue $\mathrm{PC} 2$ is much more abundant than $\mathrm{PC} 1$ (Seidah et al., 1990, 1991; Benjannet et al., 1991; Day et al., 1992). From these biochemical studies it is concluded that PC1 and PC2 represent distinct prohormone convertases that produce distinct sets of tissue-specific maturation products in the anterior and intermediate pituitary lobes. The coregulation of convertase gene expression with POMC gene expression in the intermediate lobe (Birch et al., 1991; Bloomquist et al., 1991; Day et al., 1992) further suggests the importance of a coordinate action between enzyme and substrate. We now extend these studies to the CNS by examining in detail the expression of $\mathrm{PC} 1$ and $\mathrm{PC} 2$ using in situ hybridization. Furthermore, we compare this distribution to that of furin, whose cellular CNS localization has not yet been described. Finally, these distributions are compared to that of two known processing enzymes, CPE and PAM. Our comparative data suggest that both neuronal and non-neuronal elements in the CNS are capable of specific posttranslational processing patterns that are determined by the specific expression and abundance of each of the convertases. Finally, the present data may help to provide some further insight into the combination of convertases necessary to generate tissue-specific neuropeptide products and active proteins.

\section{Materials and Methods}

Tissue preparation. Brains from male Sprague-Dawley rats (200-250 $\mathrm{gm})$ were rapidly removed and frozen in isopentane cooled to $-30^{\circ} \mathrm{C}$ to $-50^{\circ} \mathrm{C}$ on dry ice. Fifteen-micrometer-thick sections were cut on a cryostat (Hacker Instruments) in frontal, horizontal, or sagittal planes, thaw mounted on polylysine-coated slides, and stored at $-70^{\circ} \mathrm{C}$ until further processing.

Probe synthesis. ${ }^{35}$ S-labeled cRNA probes were generated for furin, $\mathrm{PC} 1, \mathrm{PC} 2, \mathrm{CPE}$, and PAM from cDNA subclones in transcription vectors. Rat (r) PCl and rPC2 cDNAs were obtained using PCR as previously described (Day et al., 1992). The rPC1 probe $[492$ nucleotides (nt)] was completely sequenced and shown to have a $97 \%$ homology to mouse (m) PC1, corresponding to nt 715-1206. The IPC2 probe (450 nt) was $95 \%$ identical to mPC2, corresponding to nt 878-1326. The furin probe corresponded to nt 691-1935 of the rat cDNA clone (Misumi et al., 1990). Following synthesis, the furin cRNA probe was exposed to mild alkaline hydrolysis to decrease probe length to $300-400 \mathrm{nt}$ as previously described (Seidah et al., 1992). The CPE probe was complementary to nt 1080-1470 of the PCR-generated rat cDNA clone (Fricker et al., 1989). The PAM probe corresponded to nt 164-1197 of the rat cDNA clone (Eipper et al., 1987) and has previously been used in situ hybridization studies (Schäfer et al., 1992). Specific activities of the generated cRNA probes were as follows: furin, $600,000 \mathrm{Ci} / \mathrm{mmol}$;
$\mathrm{PCl}$, 250,000 Ci/mmol; PC2, 240,000 Ci/mmol; CPE, 95,000 Ci/mmol; PAM, 30,000 Ci/mmol.

In situ hybridization histochemistry. In situ hybridization histochemistry was performed according to a previously reported protocol (Schäfer et al., 1992). Briefly, frozen sections were fixed in $4 \%$ phosphate-buffered formaldehyde solution for $60 \mathrm{~min}$ at $4^{\circ} \mathrm{C}$ and then washed three times in $0.05 \mathrm{M}$ PBS, pH 7.4, for $10 \mathrm{~min}$ each. Deproteination was carried out with proteinase $\mathrm{K}(1 \mu \mathrm{g} / \mathrm{ml})$ for $10 \mathrm{~min}$ at $37^{\circ} \mathrm{C}$. Slides were transferred to $0.1 \mathrm{M}$ triethanolamine, $\mathrm{pH} 8.0$, and incubated in the same solution containing acetic anhydride $(0.25 \% \mathrm{v} / \mathrm{v})$ for $10 \mathrm{~min}$ at room temperature (RT). Sections were then rinsed in $2 \times$ saline-sodium citrate (SSC) and dehydrated in ethanol (50-100\%). Radioactive cRNA probes were diluted in hybridization buffer [ $75 \%$ formamide, $10 \%$ dextran sulfate, $3 \times \mathrm{SSC}, 50 \mathrm{~mm} \mathrm{NaPO}$, pH 7.4, $1 \times$ Denhardt's $(0.02 \%$ each of Ficoll 400 , polyvinylpyrrolidone, BSA), $0.1 \mathrm{mg} / \mathrm{ml}$ yeast RNA] to a final concentration of $34 \times 10^{4} \mathrm{dpm} / \mu \mathrm{l}$. Dithiothreitol was added to a final concentration of $10 \mathrm{~mm}$. Hybridization mix (30-50 $\mu \mathrm{l}$ per slide) was applied and sections were coverslipped and sealed with rubber cement. The tissue was incubated in the hybridization oven at $55^{\circ} \mathrm{C}$ for $16 \mathrm{hr}$. The next day coverslips were removed in $2 \times$ SSC. Sections were treated with RNase A $(200 \mu \mathrm{g} / \mathrm{ml})$ at $37^{\circ} \mathrm{C}$ for $60 \mathrm{~min}$ to remove single-stranded RNA molecules. Successive washes followed at RT in $2 \times, 1 \times, 0.5 \times$, and $0.2 \times \mathrm{SSC}$ for $10 \mathrm{~min}$ each and in $0.2 \times \mathrm{SSC}$ at $60^{\circ} \mathrm{C}$ for $1 \mathrm{hr}$. The tissue was then dehydrated and exposed to Kodak XAR x-ray film from 1-4 (CPE, $1 \mathrm{~d} ; \mathrm{PC1}, \mathrm{PC} 2$, furin, and PAM, $4 \mathrm{~d}$ ). For microscopic analysis, sections were dipped in Kodak NTB2 nuclear emulsion and stored at $4^{\circ} \mathrm{C}$. Following exposure times from 1 to 8 weeks (CPE, $6 \mathrm{~d}$; $\mathrm{PCl}$, PC2, furin, and PAM, $30 \mathrm{~d}$ ), autoradiograms were developed in Kodak D1 9 at full strength for 2 min and fixed in Rapid Fix (Kodak) for $4 \mathrm{~min}$. To identify cellular structures, some of the autoradiograms and some adjacent nonhybridized sections were counterstained with cresyl violet.

Controls. The same cRNA probes for furin, $\mathrm{PCl}$, and $\mathrm{PC} 2$ have been shown previously in Northern blot analysis to recognize the correct mRNA sizes (Day et al., 1992). As negative in situ controls, tissues were either treated with RNase A $\left(200 \mu \mathrm{g} / \mathrm{ml}\right.$ at $37^{\circ} \mathrm{C}$ for $\left.60 \mathrm{~min}\right)$ prior to hybridization or probed with the sense-strand probes of the same size and specific activity. Positive labeling was never encountered in these experiments.

\section{Results}

The mRNA distribution of the mammalian convertases furin, $\mathrm{PC1}$, and PC2 have been mapped in the adult rat brain and their distribution compared with CPE and PAM. These results are illustrated in Figures 1 and 2 and summarized in Table 1. In general, brain regions with high levels of CPE or PAM mRNA also exhibited relatively high mRNA levels of at least one of the endoproteolytic cleavage enzymes. Although a quantitative analysis of mRNA levels was not performed, a qualitative comparison between the different brain regions could be made for each enzyme mRNA. Considering exposure time length of the autoradiograms and the difference in specific activities of the cRNA probes used, CPE mRNA, with autoradiogram exposure times of 1 week, was clearly the most abundant of the enzyme mRNAs studied in almost all examined regions. Using $\mathrm{PCl}$ and PC2 cRNA probes of similar length and specific activity, the mRNA levels of these two enzymes were more comparable. PC2 showed a broader distribution in various brain regions, but with a preferential localization in neuronal tissue. $\mathrm{PCl}$ was more restricted in its distribution pattern, but was expressed in high levels in some regions, which will be described in more detail below. Compared to CPE mRN $\Lambda$, levels PC1 and PC2 mRNAs were in general a factor of 10 -fold lower, and compared to PAM mRNA, 1- or 2-fold lower. Furin mRNA exhibited the lowest expression levels of all enzymes studied. These estimates of relative abundance compare well with that observed with Northern blot analysis of various brain regions (data not shown). It should be noted that occasionally higher labeling was observed 

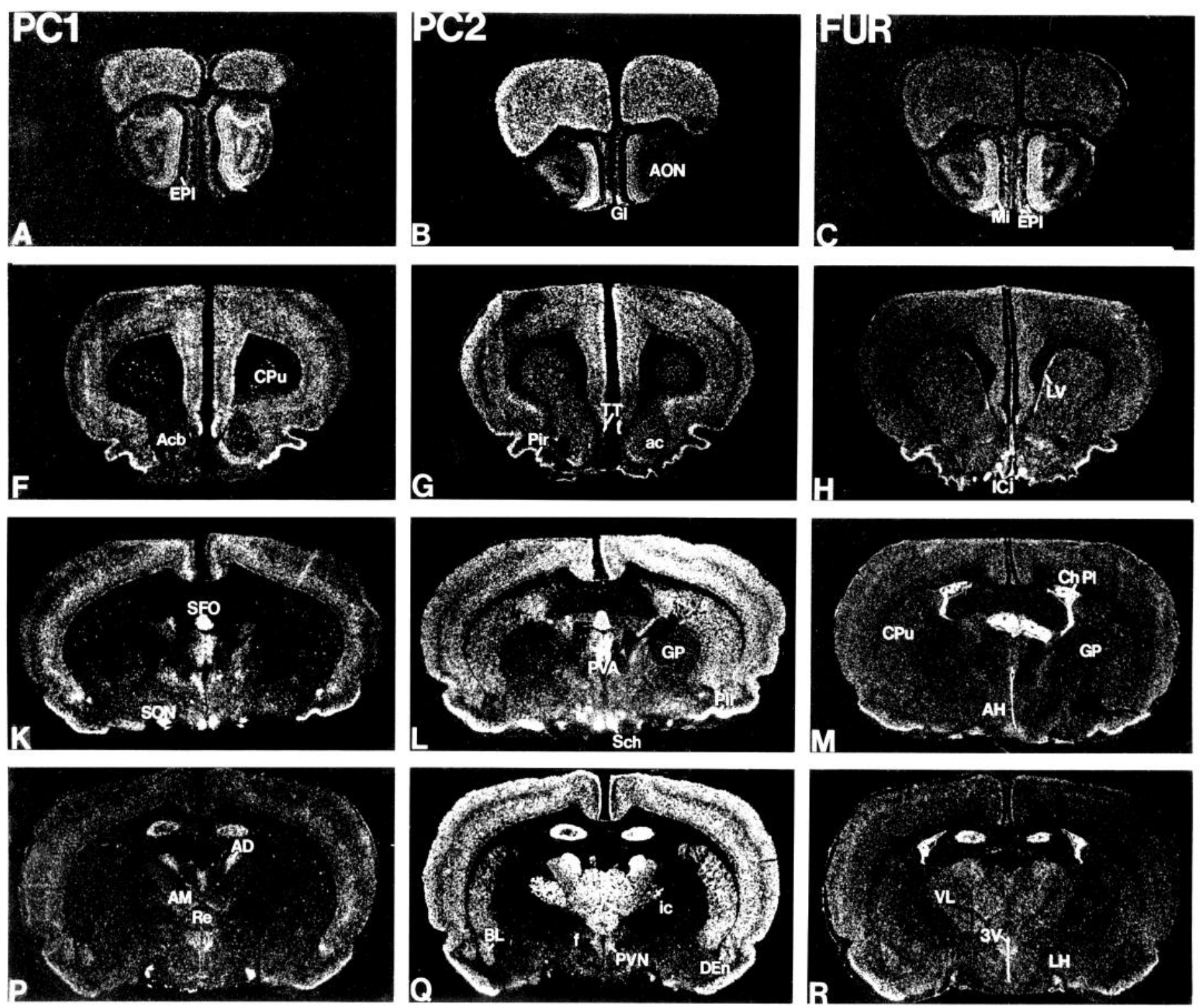

on one side of the brain sections (see Figs. 1, 2), but these differences could never be confirmed in adjacent sections, and are most likely due to variations in the in situ hybridization method.

\section{Anatomical distribution of furin $m R N A$}

The expression of furin mRNA in the rat CNS was ubiquitous. All brain areas exhibited low to moderate levels (Figs. 1, $2 C, H, M, R)$. Following exposure times of $30 \mathrm{~d}$, positive labeling could be detected both in neuronal and non-neuronal tissues as listed in Table 1, and was not confined to known neuropeptiderich regions. Interestingly, some brain regions exhibited relatively high levels of furin mRNA. These included areas of the olfactory bulb (Fig. $1 C$ ), the piriform cortex (Fig. $1 H$ ), the hippocampal formation (Fig. 2C), the cerebellar cortex (Fig. 2R). Non-neuronal tissues with very high levels of furin mRNA included the ventricular ependyma of the lateral ventricle (Fig. $1 H$ ) and the central canal (see Fig. 12B), the choroid plexus (Fig. $1 M$ ), and the circumventricular organs, including the subfornical organ (Fig. $1 M$ ) and the area postrema (Fig. 2R).
Surprisingly, the highest levels of furin mRNA were observed over the granular cells of the islands of Calleja (Fig. 4B,C), which also expressed moderate levels of CPE (Fig. 4.A). PC1 and PC2 mRNA were not detectable in this tissue. Higher-magnification analyses suggested that the observed higher levels of furin mRNA in the brain regions described above are not simply due to a greater "packing density" of the cells in these areas, but rather that individual cells express relatively higher levels of furin mRNA.

\section{Distribution of $P C I$ and $P C 2$ MRNA}

Olfactory system. In the olfactory bulb a moderate to dense labeling was observed for both $\mathrm{PC} 1$ and $\mathrm{PC} 2 \mathrm{mRNA}$ in distinct layers (Fig. $1 A, B$ ). PC2 mRNA was observed in many cell types at moderate levels including the tufted cells, the mitral cells, and the periglomerular and granular cells (Table 1). PCl mRNA was expressed at higher levels than PC2 mRNA only in the tufted cells and in the anterior olfactory nucleus. In the other cell layers $\mathrm{PCl}$ mRNA was present only at low levels of expression. Interestingly, while furin mRNA was present in all 

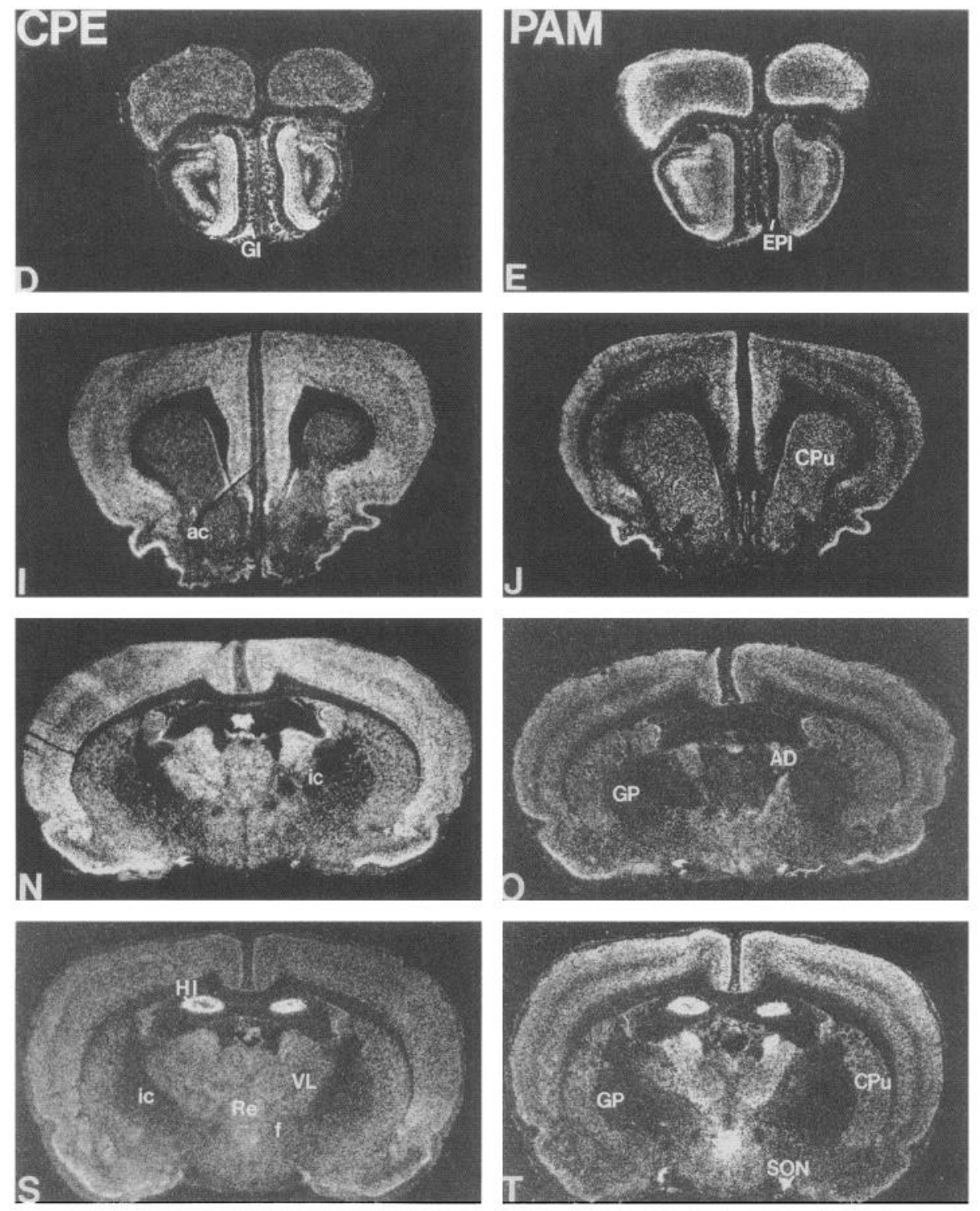

Figure 1. Comparative distribution of mRNAs coding for the processing enzymes $\mathrm{PCl}(A, F, K, P), \mathrm{PC} 2(B, G, L$, $Q)$, furin $(C, H, M, R), \mathrm{CPE}(D, I, N$, $S)$, and PAM $(E, J, O, T)$ in several brain regions. Dark-field autoradiograms of coronal sections in rostral to caudal orientation show clusters of grains after hybridization with ${ }^{35} \mathrm{~S}$-labeled cRNA probes. X-Ray film exposures were as follows: $\mathrm{PC} 1, \mathrm{PC} 2$, furin, and PAM, $96 \mathrm{hr}$; CPE, $24 \mathrm{hr}$. See Appendix for abbreviations used in Figures 1-12. cell layers at moderate levels, it was very highly expressed in the tufted cells and the external plexiform layer (Fig. $1 C$ ). All olfactory regions expressed CPE and PAM mRNA at moderate to high levels (Table 1).

\section{Telencephalon}

Neocortex. In the cerebral neocortex, $\mathrm{PC} 1$ and $\mathrm{PC} 2$ mRNAs were heterogeneously distributed. PC1 was expressed in temporal cortex at moderate levels in layers $2-6$, with higher expression levels in the deep layers and low to undetectable levels in portions of layers 4 and 5 (Fig. $1 K$ ). PC2 mRNA, imitating the distribution pattern of PAM (Fig. 1T), was highly expressed in layers 2-3 and 5-6, but very low to absent in layer 4 (Fig. $1 Q$ ). In contrast, furin mRNA expression was highest in layer 4 , with low levels of expression in all other cortical layers (Figs. $1 R, 2 C)$.

Hippocampal formation. High levels of RNA transcripts encoding all enzymes were present in the hippocampal formation. While furin mRNA was expressed at very high levels in all hippocampal subregions (Fig. 2C), PC1 and PC2 mRNAs showed distinct differences in distribution. In the pyramidal cells of the subfields CA1-CA4, PC2 mRNA was more abundant than PC1 (Fig. $3 B$ ), whereas the reverse was observed in the granular cell layer of the dentate gyrus, which exhibited higher levels of $\mathrm{PCl}$ mRNA (Fig. 3A). The expression patterns of CPE and PAM mRNA were similar to that of $\mathrm{PC} 2$.

Amygdala. Distinct distribution patterns for PC1 and PC2 were observed in the peptide-rich nuclei of the amygdaloid body. While all enzymes were present in the basolateral nucleus of amygdala at medium to high levels (Fig. $2 A-E$ ), PC2 mRNA was more abundant than $\mathrm{PC} 1$ in this region. In contrast, in the basomedial and medial nucleus and in the anterior cortical nucleus the relative levels were reversed. The central nucleus expressed the lowest levels of any enzyme mRNA.

\section{Basal forebrain areas}

All enzyme mRNAs were present in the rostral forebrain including the septal nuclei, bed nucleus of stria terminalis, and diagonal band nuclei (Fig. 1, Table 1) with strong region-specific differences. For example, in the lateral septal nucleus, PC2 

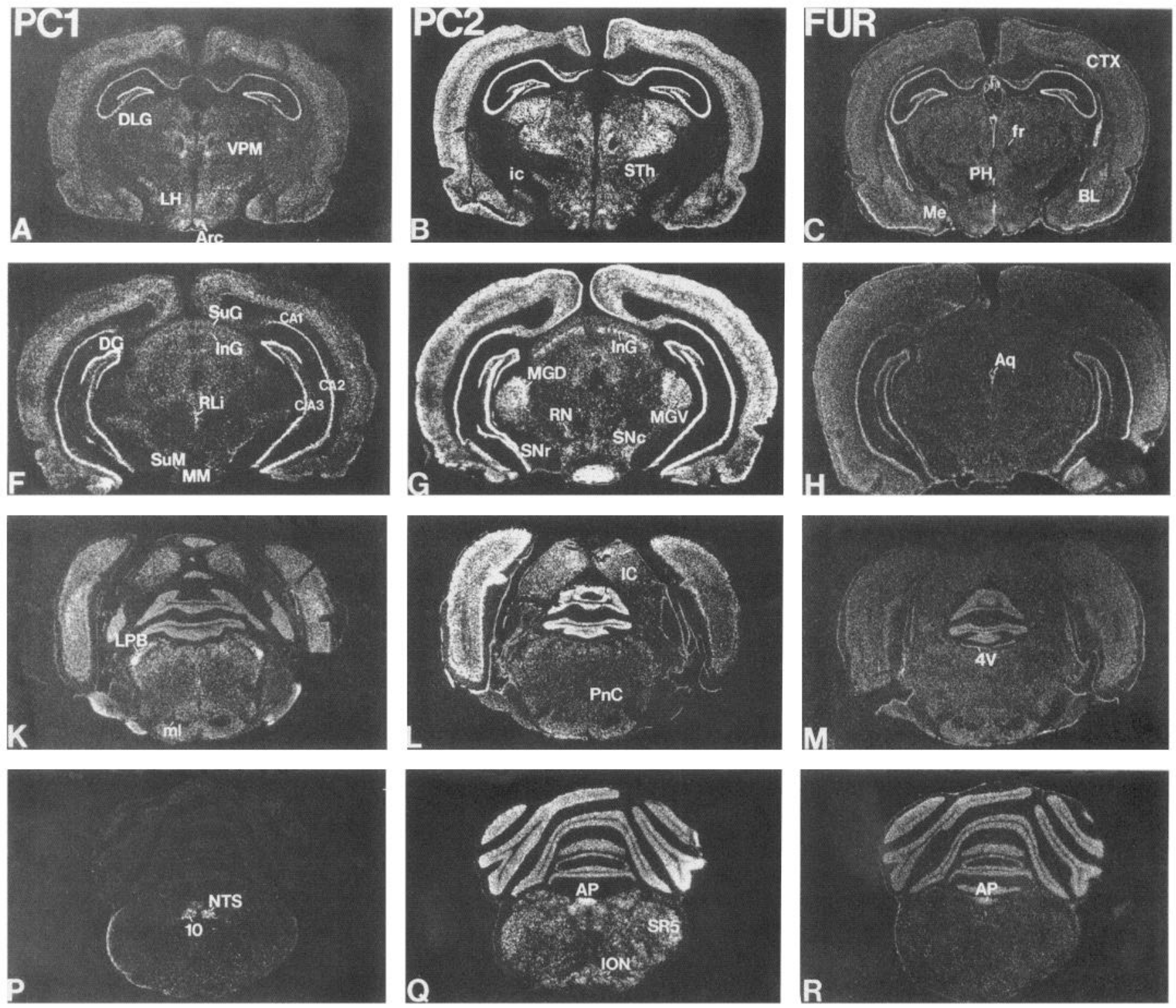

mRNA was expressed at high levels in the dorsal subdivision, furin and CPE mRNAs were also present, but neither PC1 nor PAM mRNA could be detected, suggesting the potential initial processing of precursors to nonamidated peptides by $\mathrm{PC} 2$ and/ or furin. In the anterior portion of the medial preoptic nucleus, $\mathrm{PC} 1 \mathrm{mRNA}$ was more abundant than PC2, while furin, $\mathrm{CPE}$, and PAM were present at moderate to high levels. Similarly, in the bed nucleus of the stria terminalis, PCl mRNA was expressed at higher levels than PC2. A striking distribution pattern was observed in the granule cells of the islands of Calleja (Fig. 4), which are known to synthesize no identified neuropeptides, but which exhibited one of the highest levels of furin mRNA in the entire brain, as well as high levels of CPE mRNA. Transcripts coding for PC1, PC2, and PAM were not detectable. The subfornical organ showed a striking high expression for all enzyme genes, in particular for furin and PC1 (Fig. $1 K, M$ ).

Basal ganglia. All the enzyme mRNAs were expressed throughout the basal ganglia. In the caudate-putamen, mRNAs coding for PC2 and CPE were expressed at moderate to high levels (Fig. 1), while furin and PAM were expressed at lower levels. Regional expression of PC1 mRNA in caudate-putamen was low (Fig. 1). However, upon closer inspection, a small percentage of striatal cells exhibited relatively high levels of PC1 mRNA (Fig. 5). Counterstaining of these and adjacent sections revealed that $\mathrm{PC} 1 \mathrm{mRNA}$ was expressed over large neurons (Fig. 5A), resembling the cholinergic neurons in size and distribution (Bolam et al., 1984; Heimer et al., 1985). Numerous small and medium-size neurons throughout the caudate-putamen expressed moderate levels of PC2 mRNA (Fig. $5 B$ ). These include most likely the medium spiny striatopallidal projection neurons, known to synthesize proenkephalin-derived opioid peptides. In the nucleus accumbens and ventral pallidum, enzyme transcript levels were low to moderate with a higher expression of PC2 than PC1 mRNA (Fig. $1 F, G$ ), with the exception of the few scattered large-size neurons exhibiting high levels of PC1 mRNA. The globus pallidus exhibited only low levels of PC2 mRNA, and PCl mRNA was close to detection limit (Fig. $1 K, L)$. 

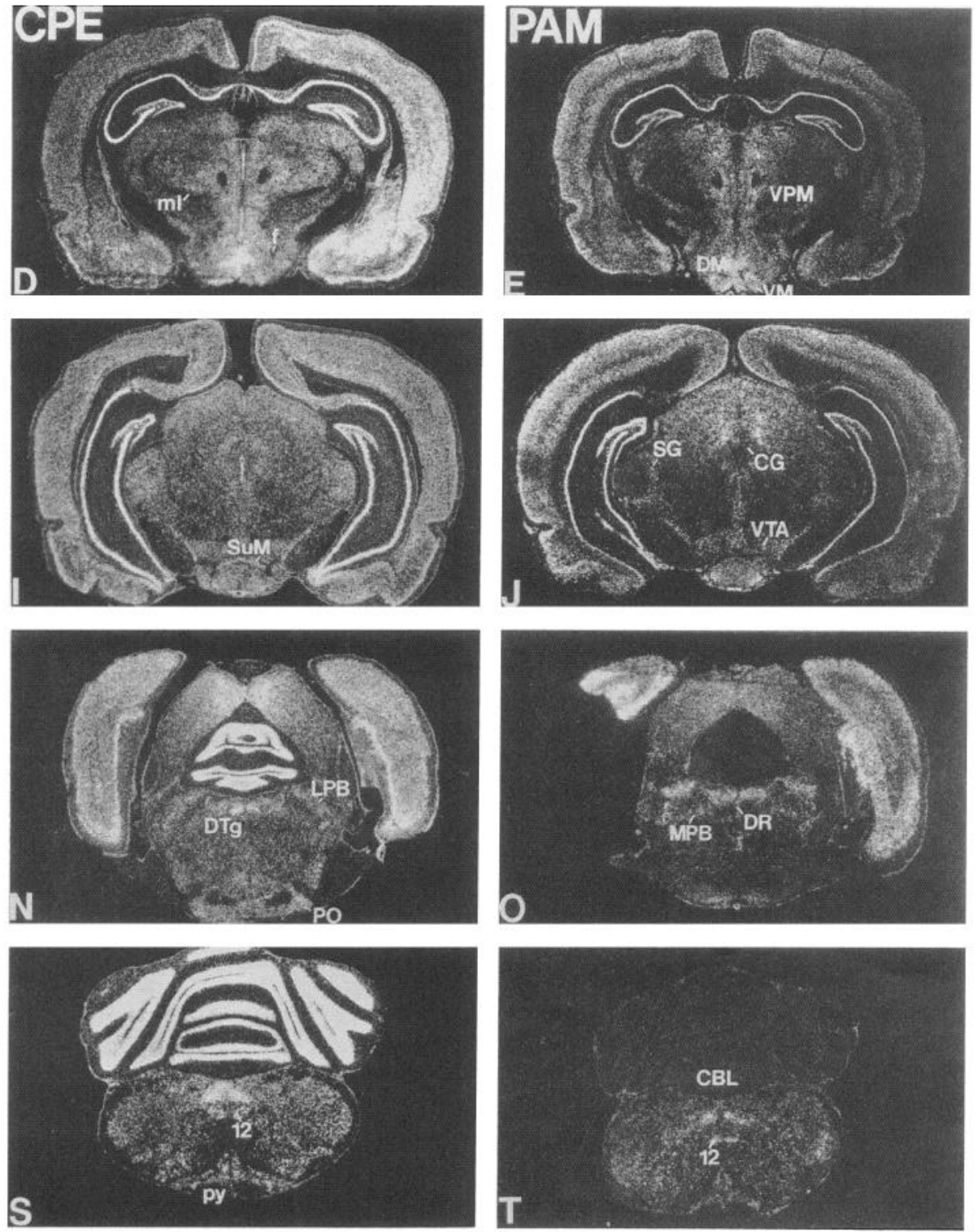

Figure 2. Comparative distribution of mRNAs coding for the processing enzymes PC1 $(A, F, K, P), \operatorname{PC} 2(B, G, L$, $Q)$, furin $(C, H, M, R), \mathrm{CPE}(D, I, N$, $S)$, and PAM $(E, J, O, T)$ in several brain regions caudal to those shown in Figure 1. Dark-field autoradiograms of coronal sections in rostral to caudal orientation show clusters of grains after hybridization with ${ }^{35}$ S-labeled cRNA probes. X-Ray film exposures were as follows: PC1, PC2, furin, and PAM, 96 $\mathrm{hr}$; CPE, $24 \mathrm{hr}$.
Choroid plexus. In the region of the rostral forebrain, high levels of furin and CPE mRNA were observed in non-neuronal tissue such as the choroid plexus (Fig. 6B,E). PAM mRNA, as previously described, was present in the ventricular ependymal cells together with furin and CPE (Schäfer et al., 1992), particularly concentrated in the region of the anterior horn of the lateral ventricle neighboring the caudate-putamen (Fig. $6 F$ ). Neither PC1 or PC2 transcripts could be detected in these nonneuronal tissues, but they were prominent in neighboring structures including hippocampus, thalamus, and striatum.

\section{Diencephalon}

Thalamus. Throughout the thalamus, previously shown to be rich in processing enzyme content of CPE and PAM, high expression levels of PC2 mRNA were noted, with the exception of the reticular nucleus and the posterior thalamic group (Fig. 1). The thalamic expression of PC1 mRNA was much more restricted. Relatively high levels were seen in the anterodorsal nucleus, here coinciding with high levels of PAM mRNA, and the paraventricular region. Low to undetectable levels observed in the ventral nuclei. In the reuniens nucleus, no PC1 mRNA could be detected, but a dense labeling for PC2 mRNA was observed (Fig. 1P,Q). PAM mRNA distribution was almost identical to that of $\mathrm{PC} 2$, with less labeling over the ventrolateral nucleus and the midline nuclei (Fig. 1Q,T). The expression patterns of PC2 and PAM mRNA were reminiscent of that reported for the mRNA coding for the amidated peptides cholecystokinin and the chromogranins (Ingram et al., 1989; Mahata et al., 1991). Furin mRNA was expressed only at low levels (Fig. 1R).

Habenula. The habenula, a region with known expression of amidated neuropeptides such as the tachykinins (Burgunder and Young, 1989), exhibited high levels of PC1 and PC2 with distinct distribution patterns (Fig. 7). While PC1 mRNA was more abundant in the lateral part of the medial habenula, the reverse was true for the expression of PC2 mRNA in the medial part. In the ventral portion of the lateral habenula, $\mathrm{PCl} \mathrm{mRNA}$ was more highly expressed than PC2, and high levels of expression of PAM transcripts were noted or previously reported (Schäfer et al., 1992). 


\section{Table 1. Regional distribution of mRNAs coding for processing enzymes in the rat brain}

Region

Telencephalon

Olfactory bulb

Tufted cells

Mitral cells

Ependymal cells

Granule cells

Periglomular cells

Anterior olfactory ncl.

Olfactory cortex

Piriform cortex

Tenia tecta

Olfactory tubercle

Cerebral cortex

Layer I

Layer II

Layer III

Layer IV

Layer V

Layer VI

Hippocampal formation

CA1
CA2
CA3
CA4

Scattered hilar cells

\section{Dentate gyrus}

Molecular layer

Granular layer

Islands of Calleja

Nucleus accumbens

Caudate-putamen

Globus pallidus

Ventral pallidum

Amygdala

Medial ncl.

Central ncl.

Anterior cortical ncl.

Basomedial ncl.

Basolateral ncl.

Septum

Lateral

Lateral, dorsal part

Medial

Nucleus of diagonal hand

Subfornical organ

Bed nucleus of stria terminalis

Anterior medial preoptic ncl.

Medial preoptic area

Choroid plexus

Ependyma of lateral ventricle

Diencephalon

Thalamus

Periventricular ncl.

Anteroventral ncl.

Anteromedial ncl.

Anterodorsal ncl.

Centrolateral ncl.

Centromedial ncl.
Furin

PCl

PC2

CPE

PAM

$\begin{array}{lll}1+++ & +++ & ++ \\ ++ & + & ++ \\ ++ & 0 & 0 \\ ++ & 0 /+ & + \\ ++ & + & ++ \\ +++ & +++ & ++++ \\ +++ & +++ & ++++ \\ +++ & +++ & +++ \\ +++ & ++++ & +++ \\ +++ & 0 & ++\end{array}$

$\begin{array}{lll}++ & 0 & 0\end{array}$

$++\quad++$

$++\quad++$

$+++$

$++$

$++$

$+$

$+++$

$+++$

$+++$

$++$

$+++$

$+++$

$+++$

0

$++$

$+++$

$++++$

$++$

$++$

$++$

$++$

$+++++$

0

$+$

$+++++^{*}$

$0 /+$

$+$

$+++$

$++$

$++$

$+$

$+$

$+++$

$++$

$++$

$++$

$+++$

$++$

$++$

$++$

$++$

$++$

$++$

11
$++$

$++t$

$+$

$+++$

$+++$

$++++$

$+++$

$++++$

$+++$

$+++$

0

$++$

$0 /+$

$++$

$+++$

$+$

$++$

$++++$

$+++$

$++$

$++$

$+++$

$+++$

$++++$

$+++++$

$+++++$

$++$

$+$

$++$

$++$

$+++$

$++$

$++$

$++++$

$++++$

$++++$

$++++$

$+++$

$++$

$+++$

$++$

$+$

$+++$

$++$

$+++$
$+++$

$0 /+$

$++$

$++$

$++$

$++$

0

$++$

$++$

$+++$

$+++$

$++++$

$++$

0

0

$++$

$++$

$0 /+$

$+$

$+$

$++++$

$++$

$++++$

$+++$

$++$

$++$

$+$

$+$

$+$

0

0

$++$

$++$

$+$

$++$

$+++$

$++$

$+1+$

$++$

$+++$

$+++$

$++$

$++$

$++$

$+++$

$++$

$++$

$+++$

$+$

$+++$

$+++$

$++++$

$+++$

$++$

+++
+++
+++
+++
+++
$+$

$+$

$+t+$

$+$
$++$

$++$

$++$

$++$

$++$

$+++$

$+++$

$+++$

$+++$

$+++$

0

$+++$

$+++$

$++$

$+++$

$++$

$+++$

$+++$

$++++$

$++++$

$++$

$+$

$++$

$0 /+$

$++$

$++$

$+$

$+$

$++$

$++$

$++$

$++$

$+t+$

$++$

0

$+$

$++$

$++$

$++$

$+++$

$+t+$

0

$+$

$+++$ 
Table 1. Continued

\begin{tabular}{|c|c|c|c|c|c|}
\hline Region & Furin & $\mathrm{PCl}$ & $\mathrm{PC} 2$ & $\mathrm{CPE}$ & PAM \\
\hline Mcdiodorsal ncl. & +1 & +++ & $111+$ & $t++$ & ++ \\
\hline Paraventricular ncl. & ++ & +++ & ++++ & +++ & +++ \\
\hline Reuniens ncl. & + & 0 & +++ & +++ & ++ \\
\hline Posterior group & ++ & 0 & +++ & +++ & ++ \\
\hline Reticular ncl. & + & ++ & + & ++ & + \\
\hline Rhomboid ncl. & $+t$ & +++ & ++++ & ++++ & ++ \\
\hline Ventrolateral ncl. & ++ & $0 /+$ & ++++ & ++++ & ++++ \\
\hline Ventromedial ncl. & ++ & $0 /+$ & +++ & ++++ & $+++t$ \\
\hline Xiphoid ncl. & ++ & +++ & +++ & +++ & ++ \\
\hline Dorsal lateral geniculate ncl. & ++ & 0 & +++ & & $0 /+$ \\
\hline \multicolumn{6}{|l|}{ Medial geniculate ncl. } \\
\hline Dorsal & + & $0 /+$ & +++ & +++ & +++ \\
\hline Ventral & + & $0 /+$ & +++ & +++ & + \\
\hline Medial & + & $0 /+$ & ++++ & +++ & + \\
\hline Marginal zone & + & +++ & + & ++ & +++ \\
\hline Suprageniculate ncl. & + & +++ & + & ++ & +++ \\
\hline \multicolumn{6}{|l|}{ Habenula } \\
\hline \multicolumn{6}{|l|}{ Medial } \\
\hline Lateral part & +++ & ++ & + & $++t$ & ++++ \\
\hline Medial part & +++ & + & ++++ & +++ & ++++ \\
\hline Lateral & +++ & ++ & + & +++ & $++++^{*}$ \\
\hline \multicolumn{6}{|l|}{ Hypothalamus } \\
\hline Suprachiasmatic ncl. & ++ & +++ & ++ & ++ & ++ \\
\hline Periventricular ncl. & +++ & ++++ & + & +++ & ++++ \\
\hline Supraoptic ncl. & +++ & +++++ & +++ & +++ & +++++ \\
\hline \multicolumn{6}{|l|}{ Paraventricular ncl. } \\
\hline Magnocellular part & +++ & ++++ & ++ & +++ & ++++ \\
\hline Parvocellular part & ++ & ++ & +++ & +++ & +++ \\
\hline Arcuate ncl. & ++ & +++ & ++ & +++ & +++ \\
\hline Lateral hypothalamic area & +++ & $+++++^{*}$ & $++++^{*}$ & ++++ & $++++^{*}$ \\
\hline Ventromedial ncl. & ++ & + & ++ & +++ & ++++ \\
\hline Dorsomedial ncl. & ++ & $+t+$ & +++ & +++ & +++ \\
\hline Tubcromammillary ncl. & $1+$ & $1+11$ & 11 & $1+t$ & ++++ \\
\hline Medial mammillary ncl. & ++ & + & ++++ & +++ & + \\
\hline Lateral mammillary ncl. & ++ & + & +++ & +++ & ++ \\
\hline Supramammillary ncl. & ++ & +++ & ++ & +++ & ++++ \\
\hline \multicolumn{6}{|l|}{ Mesencephalon } \\
\hline Zona incerta & + & +++ & ++ & ++ & ++ \\
\hline Subthalamic ncl. & + & +++ & +++ & +++ & ++ \\
\hline \multicolumn{6}{|l|}{ Substantia nigra } \\
\hline Pars compacta & +++ & ++++ & +++ & +++ & ++++ \\
\hline Pars reticulata & + & + & +++ & +++ & + \\
\hline Ventral tegmental area & ++ & $+t$ & +++ & +++ & ++++ \\
\hline Central Gray & + & ++ & +++ & +++ & ++ \\
\hline Oculomotor ncl. & + & +++ & ++++ & +++ & ++ \\
\hline Red ncl. & ++ & ++ & ++++ & ++++ & ++ \\
\hline Edinger-Westphal ncl. & + & ++++ & 0 & +++ & ++++ \\
\hline Trochlear ncl. & ++ & +++ & ++++ & +++ & +++ \\
\hline Dorsal raphe ncl. & + & +++ & +++ & +++ & +++ \\
\hline \multicolumn{6}{|l|}{ Rostral linear nucleus of raphe } \\
\hline Lateral & + & + & ++++ & +++ & +++ \\
\hline Medial & + & ++++ & + & +++ & +++ \\
\hline Median raphe ncl. & + & +++ & ++ & +++ & +++ \\
\hline \multicolumn{6}{|l|}{ Superior colliculus } \\
\hline Superficial gray layer & + & +++ & + & ++ & +++ \\
\hline Intermediate gray layer & + & ++ & +++ & ++ & +++ \\
\hline Deep gray layer & $+/++$ & + & + & ++ & ++ \\
\hline Inferior colliculus & $+1++$ & +++ & +++ & +++ & ++ \\
\hline
\end{tabular}




\begin{tabular}{|c|c|c|c|c|c|}
\hline Region & Furin & $\mathrm{PCl}$ & $\mathrm{PC} 2$ & CPE & PAM \\
\hline Interpeduncular ncl. & ++ & ++ & $++1+++$ & +++ & $++t$ \\
\hline Pedunculopontine ncl. & + & +++ & +++ & +++ & +++ \\
\hline \multicolumn{6}{|l|}{ Pons and medulla } \\
\hline Pontine ncl. & + & +++ & ++++ & ++++ & ++ \\
\hline Dorsal tegmental ncl. & + & ++ & +++ & $++t$ & ++ \\
\hline Dorsolateral & + & +++ & ++ & ++++ & $++t+$ \\
\hline Locus coeruleus & ++ & ++ & $++t+$ & $+t+$ & ++ \\
\hline Dorsal parabrachial ncl. & + & +++ & ++ & +++ & ++++ \\
\hline Ventral parabrachial ncl. & + & +++ & +++ & +++ & +++ \\
\hline Kölliker-Fuse ncl. & + & +++ & ++ & +++ & ++++ \\
\hline Ventral tegmental ncl. & ++ & + & +++ & ++++ & ++++ \\
\hline Trigeminal motor ncl. & ++ & ++ & ++++ & ++++ & ++ \\
\hline Abducens ncl. & ++ & ++ & $+++t$ & ++++ & ++ \\
\hline Dorsal cochlear ncl. & ++ & ++++ & +++ & ++++ & +++ \\
\hline Ventral cochlear ncl. & ++ & +++ & ++++ & +++ & ++++ \\
\hline Superior vestibular ncl. & + & +++ & ++++ & +++ & ++++ \\
\hline Medial vestibular $\mathrm{ncl}$ & + & ++ & + & +++ & +++ \\
\hline Lateral vestibular ncl. & + & ++ & +++ & +++ & ++ \\
\hline Trapezoid body & ++ & ++ & ++ & ++++ & ++ \\
\hline Nucleus raphe magnus & + & +++ & + & +++ & ++++ \\
\hline Nucleus raphe pallidus & ++ & +++ & + & +++ & +++ \\
\hline Gigantocellular ncl. & ++ & +++ & ++++ & ++++ & +++ \\
\hline Lateral reticular ncl. & ++ & +++ & ++++ & ++++ & +++ \\
\hline Facial motor nucleus & +++ & +++ & ++++ & ++++ & +++ \\
\hline Nucleus of trigeminal tract & ++ & ++ & +++ & +++ & +++ \\
\hline Inferior olive & + & ++ & ++++ & ++++ & ++++ \\
\hline Prepositus hypoglossal ncl. & + & +++ & + & +++ & ++++ \\
\hline \multicolumn{6}{|l|}{ Nucleus of the solitary tract } \\
\hline Medial & + & ++++ & ++ & +++ & +++ \\
\hline Lateral & + & ++ & +++ & +++ & ++++ \\
\hline Dorsal vagal ncl. & + & ++++ & ++ & ++++ & ++++ \\
\hline Ambiguus ncl. & + & +++ & ++ & +++ & ++ \\
\hline Hypoglossal ncl. & ++ & +++ & ++++ & +++ & $++t$ \\
\hline Cuneate ncl. & + & +++ & +++ & +++ & + \\
\hline Gracile ncl. & + & ++ & +++ & +++ & +++ \\
\hline Spinal trigeminal $\mathrm{ncl}$. & + & +++ & ++++ & ++++ & +++ \\
\hline Area postrema & +++ & ++ & +++ & +++ & +++ \\
\hline \multicolumn{6}{|l|}{ Cerebellar cortex } \\
\hline Molecular layer & ++ & 0 & $0 /+$ & +++ & 0 \\
\hline Purkinje cell layer & +++ & ++ & ++++ & +++++ & 0 \\
\hline Granular layer & + & 0 & ++ & ++++ & 0 \\
\hline \multicolumn{6}{|l|}{ Spinal cord } \\
\hline \multicolumn{6}{|l|}{ Dorsal horn } \\
\hline Superficial layer & + & +++ & +++ & +++ & ++++ \\
\hline Deep layer & + & ++ & +++ & +++ & +++ \\
\hline Lamina $X$ & $+/++$ & +++ & ++++ & ++++ & ++++ \\
\hline Ventral horn & $+/++$ & ++ & +++ & ++++ & +++ \\
\hline White matter & ++ & +++ & ++++ & +++ & +++ \\
\hline Ependyma & +++ & 0 & 0 & ++ & $0 /+$ \\
\hline
\end{tabular}

This table presents a subjective evaluation of mRNA levels in different brain areas from three animals. Density: +++++ , maximum density; ++++ , very dense; +++ , dense; ++ , moderate; + , light; 0 , below detection limit. An asterisk indicates scattered cells with high labeling density.

Hypothalamus. In the hypothalamus, the brain region with the highest concentration of neuropeptides, all processing enzyme transcripts were present with prominent region-specific differences. For example, the magnocellular neurons of the supraoptic nucleus (Fig. 8) and paraventricular nucleus (Fig. 9), well characterized in respect to their content of multiple neuropeptides, expressed significantly higher levels of PC1 mRNA than PC2 mRNA. Furin and CPE mRNA were also present in the magnocellular neurons. PAM mRNA showed the highest expression level in magnocellular neurons. The suprachiasmatic 

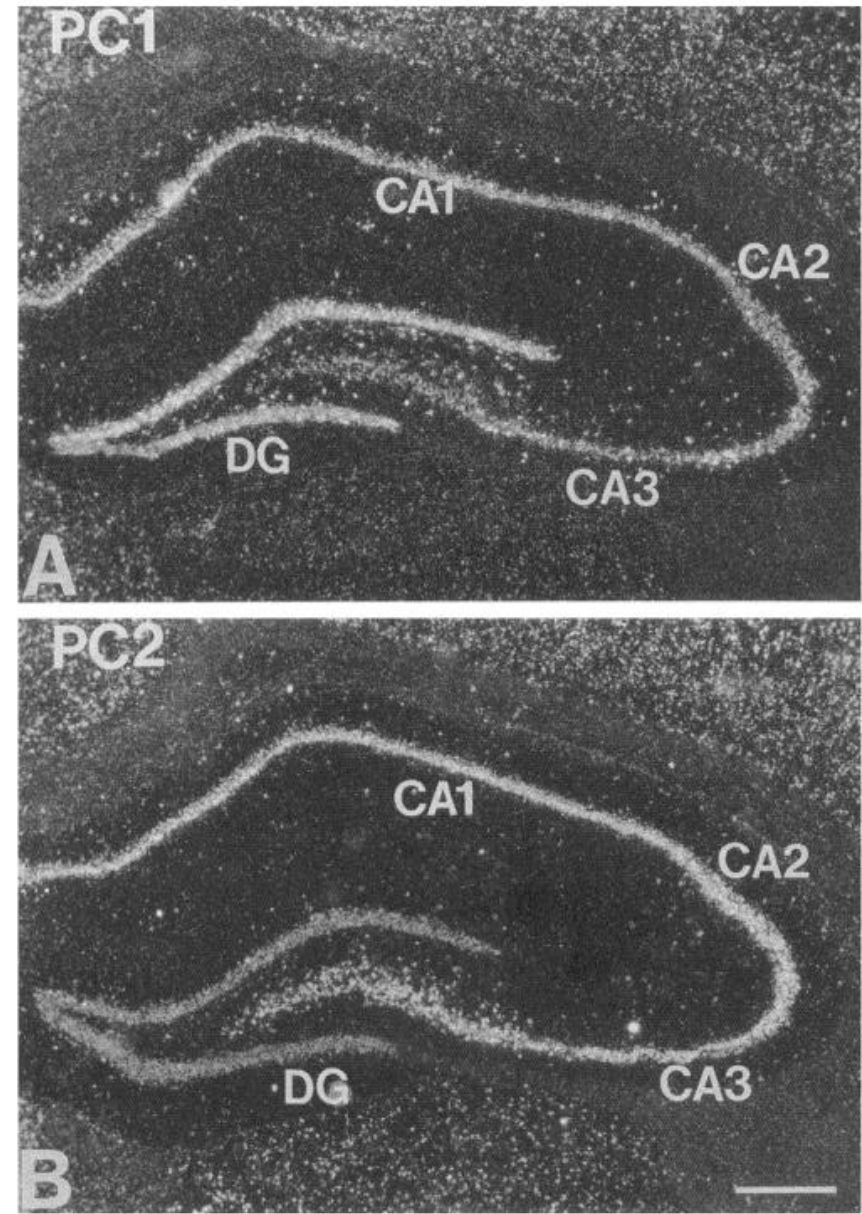

Figure 3. Localization of PC1 mRNA $(A)$ and PC2 mRNA $(B)$ in the hippocampal formation. Note the differential expression in the various subregions. $A, \mathrm{PC} 1 \mathrm{mRNA}$ is present in granular layer of $\mathrm{CA} 1-\mathrm{CA} 3$, but was most abundant in the dentate gyrus $(D G) . B$, In contrast, $\mathrm{PC} 2$ mRNA levels are the lowest in the dentate gyrus and the highest in CA2 and CA3 region. Exposure time, $30 \mathrm{~d}$. Scale bar, $0.5 \mu \mathrm{m}$.

nucleus and the medial preoptic nucleus were other areas with higher levels of PC1 mRNA than PC2 mRNA. More PC2 mRNA than PCl mRNA was found in the anterior hypothalamic area and in the parvocellular subdivisions of the paraventricular hypothalamic nucleus, particularly in the lateral and medial parvocellular neurons (Fig. 9B), known for their synthesis of the amidated peptide corticotropin-releasing hormone (CRF) (Antoni et al., 1983). Here, PCl mRNA was also present, but mainly in the scattered magnocellular neurons present in this region. CPE mRNA was also expressed at high levels with slightly higher expression in the magnocellular region. The optic tract, adjacent to the supraoptic hypothalamic nucleus contained furin and CPE mRNA, most likely in glial elements (Vilijn et al., 1989), such as astrocytes or oligodendrocytes (Fig. $8 A, D$ ). In the basal hypothalamus in the region of the arcuate nucleus, transcripts coding for both $\mathrm{PCl}$ and $\mathrm{PC} 2$ were detected (Fig. 10). While

Figure 4. Localization of furin and CPE in the islands of Calleja. In the basal forebrain the islands of Calleja exhibited a unique distribution pattern with low to moderate levels of CPE $(A)$ and very high levels of furin mRNA $(B)$. In counterstained autoradiograms the granule cells
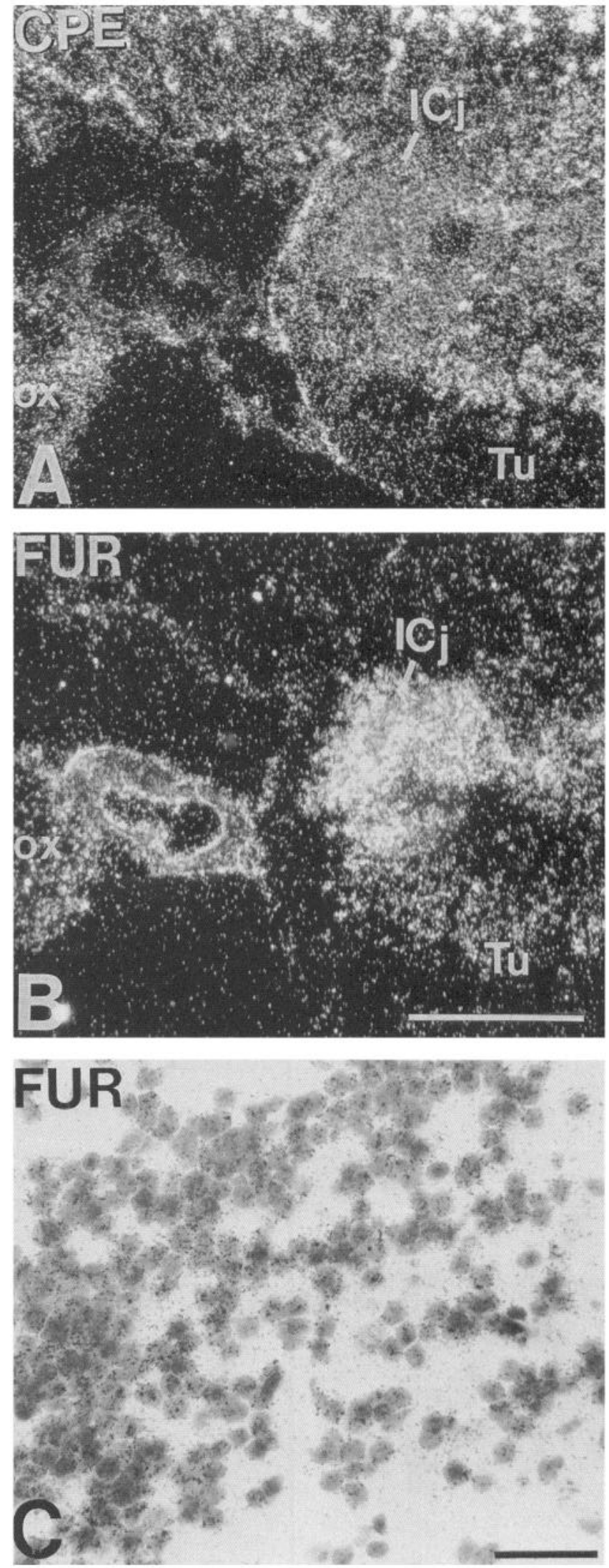

could be identified as the furin- and CPE-synthesizing cells $(C)$ that showed no labeling of PC1, PC2, or PAM mRNA. It is unclear at present what substrate protein is present in this structure. Scale bars: $A$ and $B$, $0.5 \mathrm{~mm} ; C, 50 \mu \mathrm{m}$. 

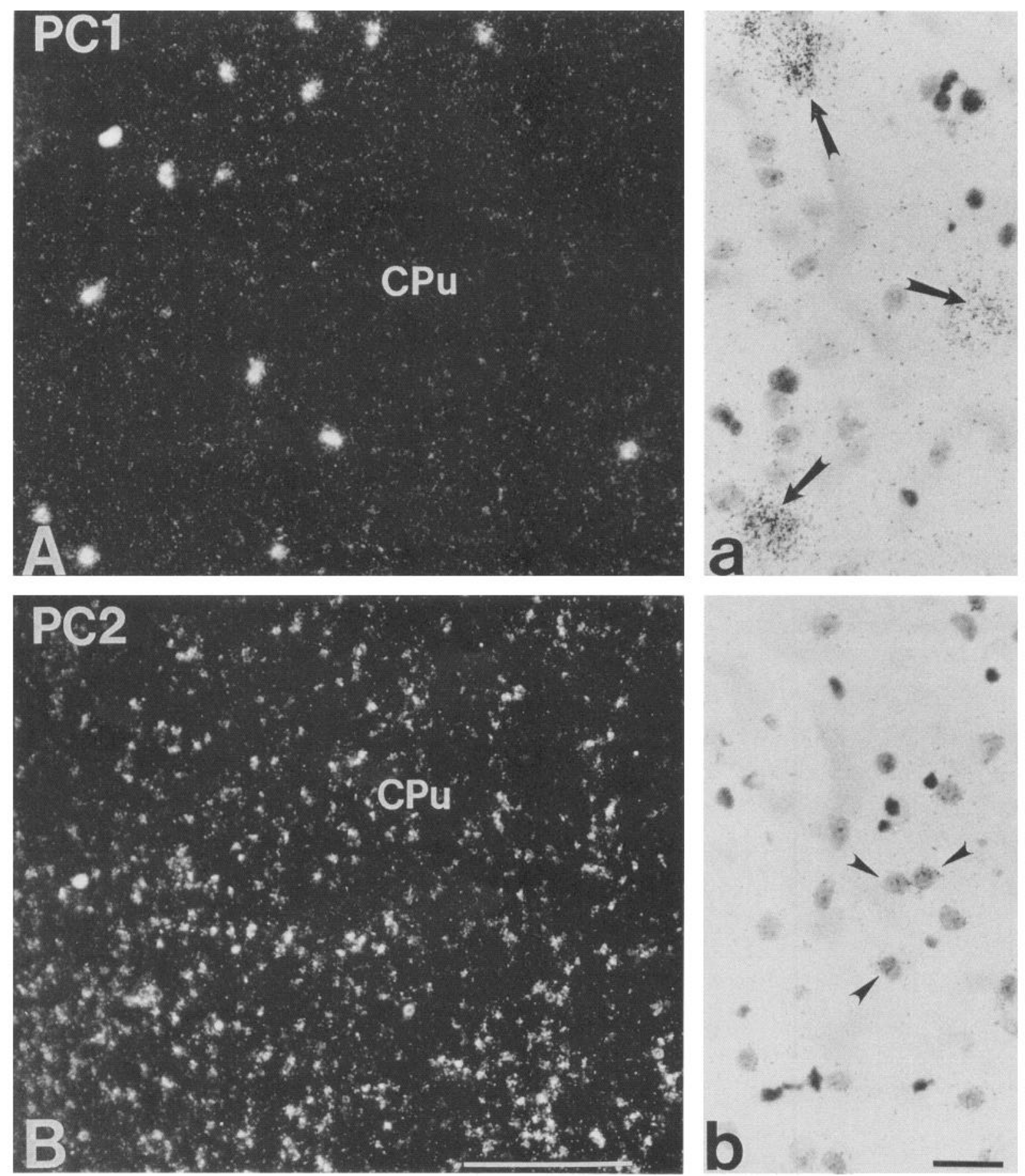

Figure 5. Expression of $\mathrm{PC} 1$ and $\mathrm{PC} 2 \mathrm{mRNA}$ in the caudate-putamen. Following exposure times of $30 \mathrm{~d}$, strong positive labeling for PC1 mRNA $(A)$ could be detected over a small percentage of scattered cells in the caudate-putamen $(C P u)$. Under bright-field examination the counterstained sections revealed that the scattered cells (arrows in $a$ ) resembled in size and distribution the cholinergic interneurons. Labeling of smaller-size neurons with the PC1 cRNA probe was weak and in most instances close to background levels $(a)$. In contrast, PC2 mRNA levels were high throughout the caudate-putamen $(B)$. Numerous small- to medium-size neurons were identified as the PC2-expressing neurons (arrows in $b$ ), which includes the proenkephalin-producing striatopallidal projection neurons. Scale bars: $A$ and $B, 0.5 \mathrm{~mm} ; a$ and $b, 50 \mu \mathrm{m}$.

Figure 6. Localization of processing enzymes in the region of the lateral ventricle. For identification of cellular structures adjacent section was counterstained with cresyl violet $(A)$. The choroid plexus and the ependyma of the lateral ventricle $(e p)$ were positively labeled when hybridized with probes coding for furin $(B)$ and CPE $(E)$. PAM mRNA $(F)$ was present in the ependyma, particularly in the region bordering the caudateputamen. No positive signal in this non-neuronal structures was observed for PC1 mRNA $(C)$ or PC2 mRNA $(D)$, which showed moderate to high expression in the neighboring neuronal areas including the hippocampus, thalamus, and cortex. Scale bar, $0.5 \mu \mathrm{m}$. 


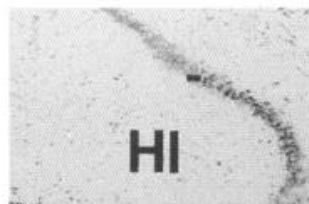

CTX

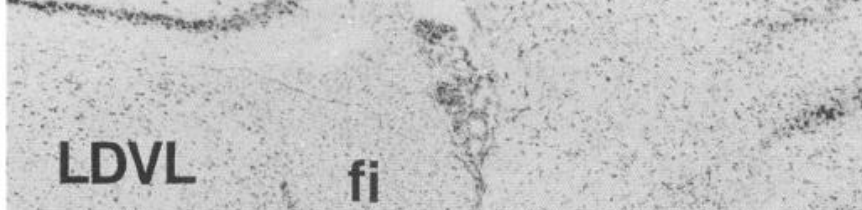

A

ic

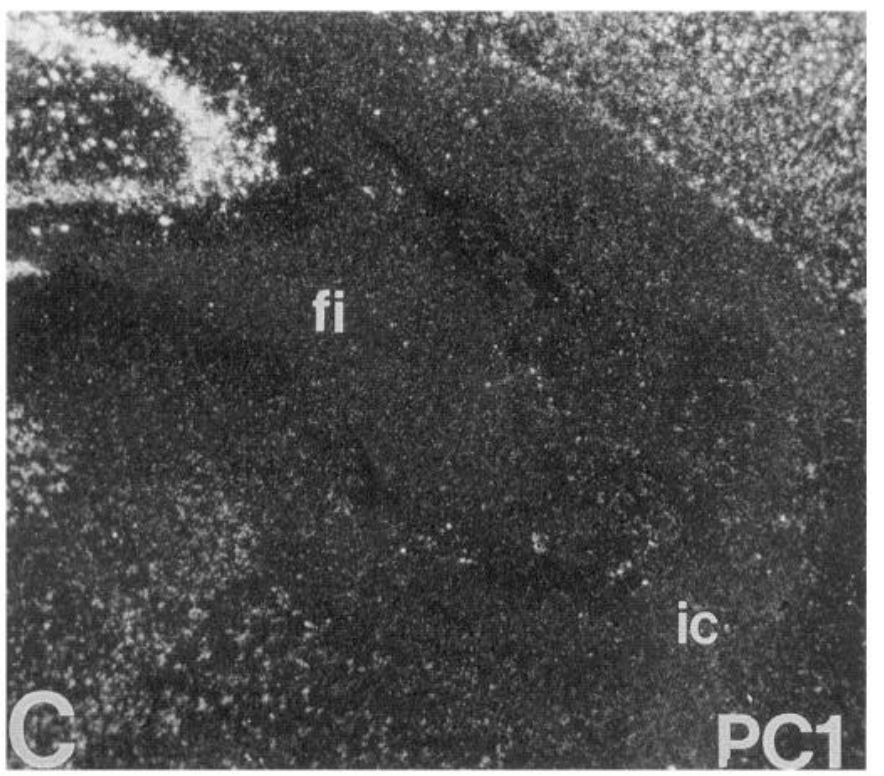

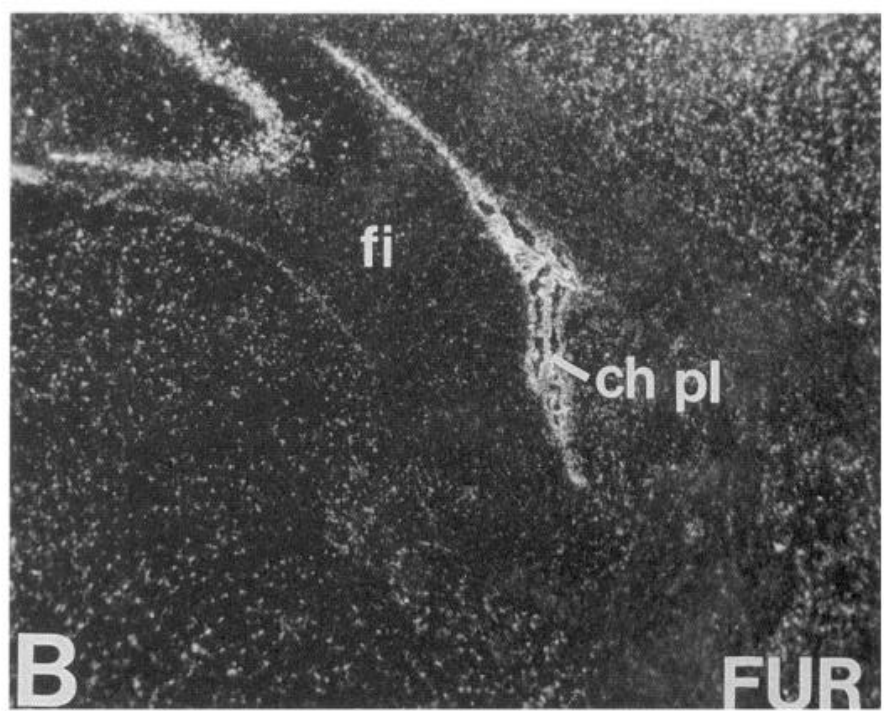
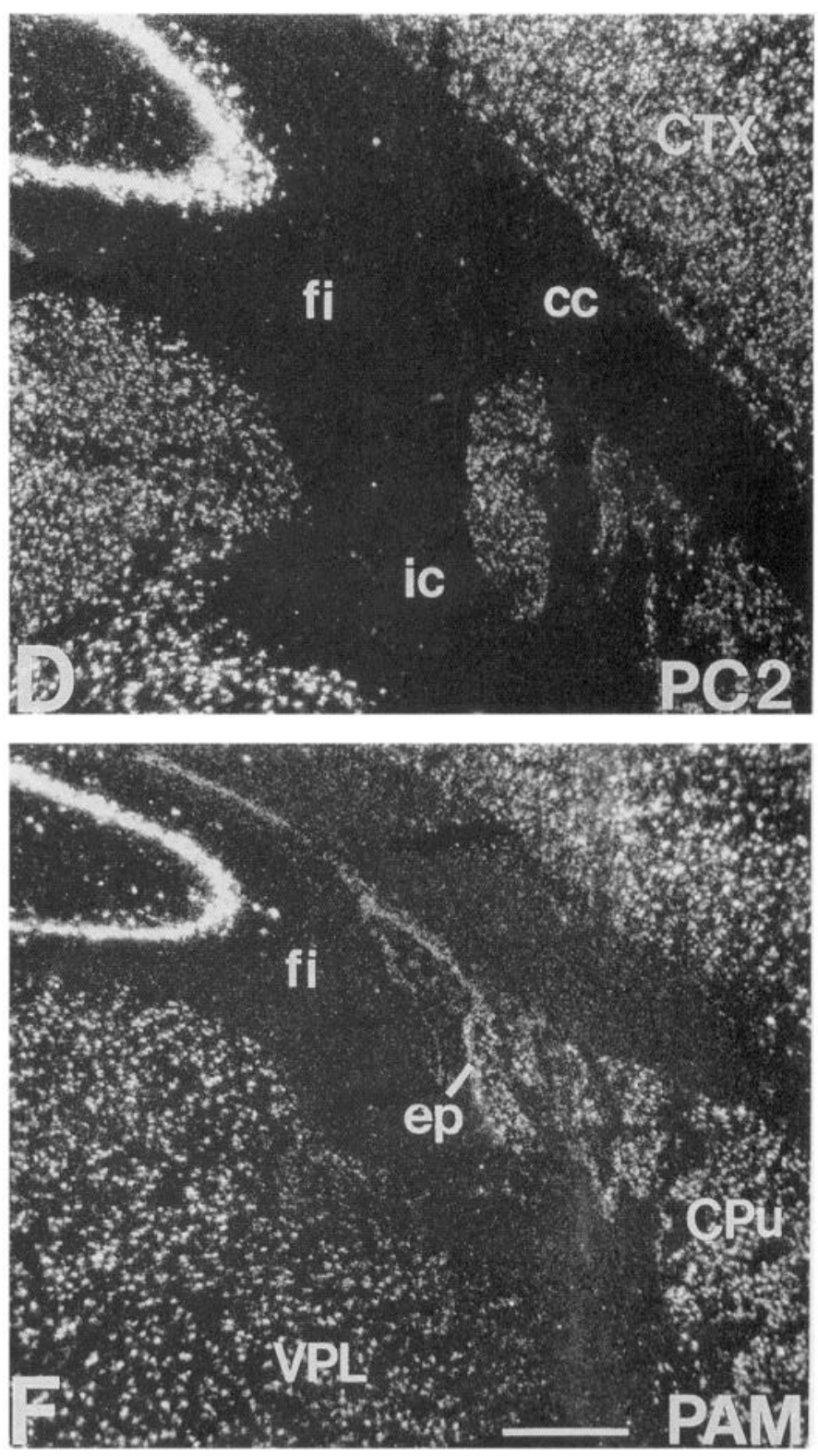

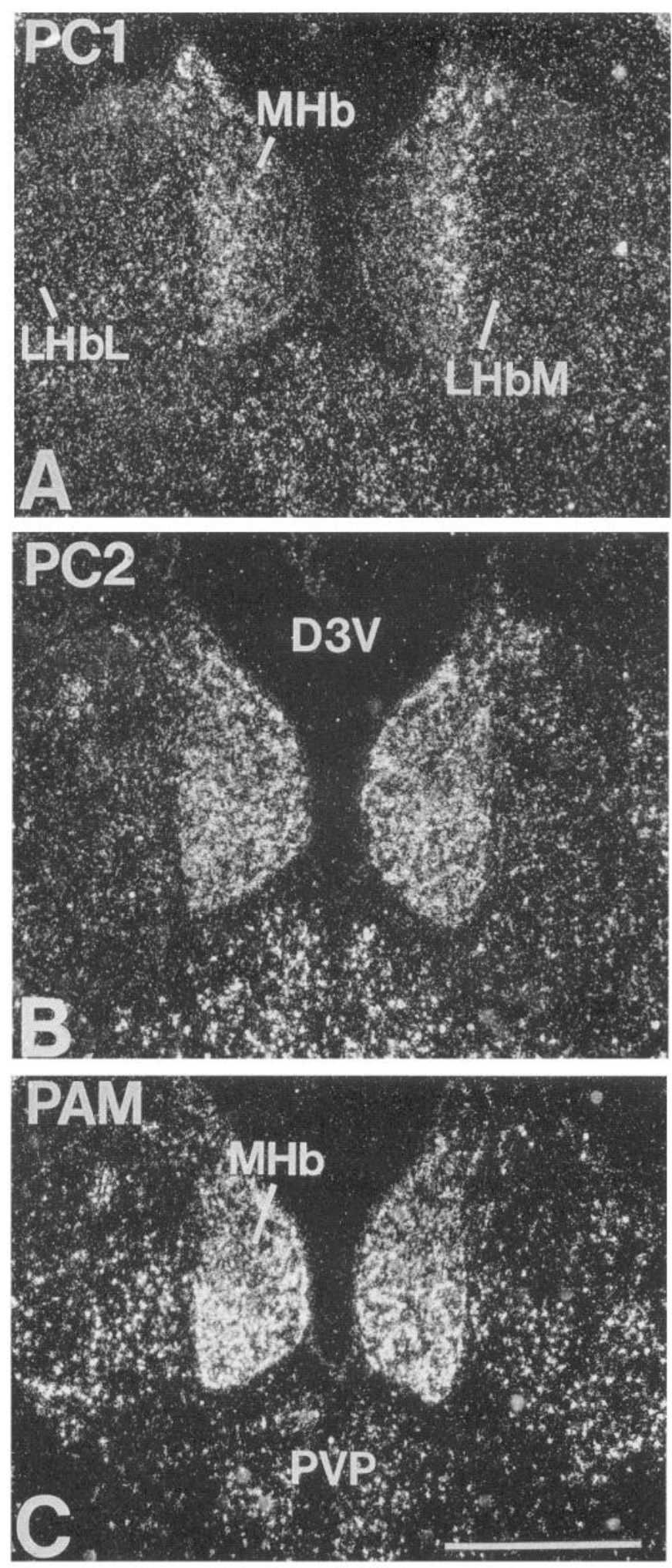

Figure 7. Differential localization of processing enzymes in the habenulae. $A, \mathrm{PC} 1 \mathrm{mRNA}$ was particularly abundant in the lateral portion of the medial habenula $(M H b)$, whereas PC2 mRNA was prominent in both medial and lateral areas of the medial habenula $(B)$. The distribution of PC2 overlapped with that of PAM mRNA $(C)$ in the medial habenula. In the ventral regions of lateral habenula, scattered neurons exhibited strong labeling for PAM mRNA $(C)$ and moderate PC1 mRNA levels $(A)$ and lower levels of PC2 mRNA $(B)$. Scale bar, $0.5 \mu \mathrm{m}$.
PC2 mRNA appeared to be more abundant in the region where POMC-producing arcuate cells are localized (Fig. 10B), PC1 was also present at lower levels, but was highly expressed in large neurons in the region ventral to the ventromedial nucleus. CPE and PAM mRNA were also present at moderate levels. The ventromedial nucleus exhibited higher levels of PC2 than PC1 mRNA. Striking regional differences were observed in the mammillary body. Here, PC1 mRNA was expressed at high levels in the supramammillary nucleus (Fig. 11 A) and the tuberomammillary nucleus, where only low to moderate expression of PC2 mRNA was seen. In contrast, in the medial mammillary nucleus PC1 mRNA levels were undetectable, but PC2 expression was relatively high (Fig. $11 B$ ). In the lateral hypothalamic area, large cells containing high levels of PC2 mRNA were observed that appeared to correspond to the melanin-concentrating hormone (MCH)-containing neurons. Other large neurons labeled prominently for $\mathrm{PCl}$ did not appear to correspond to $\mathrm{MCH}$ cells (Seidah et al., in press).

\section{Mesencephalon and rhombencephalon}

PC1 and PC2 mRNAs were detected in most regions of the mesencephalon (Table 1). In the substantia nigra, a neuropeptide-rich region functionally belonging to the basal ganglia, enzyme mRNA levels were high, particularly in the pars compacta (Fig. 11), where all were expressed at moderate to high levels. In the pars reticulata PC2 mRNA (Fig. 11B) was more abundant in scattered cells than PC1 (Fig. 11A). A similar distribution pattern was observed in the ventral tegmental area.

Higher levels of PC2 mRNA than PC1 were observed in most areas including the central gray, rostral linear nucleus, red nucleus, and the intermediate gray layer of the superior colliculus. CPE and PAM were also present at high levels. In the medial geniculate nucleus (Fig. 2) PCl was absent or expressed only at low levels with the exception of the marginal zone, where $\mathrm{PCl}$ was higher than PC2. All other subdivisions of the medial geniculate nucleus, including ventral, dorsal, and medial areas, contained relatively high levels PC2 mRNA, and the expression of PAM and CPE closely matched that of PC2 mRNA. The Edinger-Westphal nucleus expressed high $\mathrm{PCl}$ and PAM mRNA levels, but no PC2 mRNA. The rostral linear nucleus presented another example for intranuclear differences in expression of $\mathrm{PC} 1$ and PC2. In the lateral portion, high levels of PC2 mRNA were found and low expression of $\mathrm{PC1}$, whereas in the medial portion PC1 mRNA was severalfold more abundant than PC2 mRNA.

In the pons and medulla, several nuclei expressed higher levels of PC1 mRNA than PC2. These include the median raphe nucleus, the dorsal part of the parabrachial nucleus, the Kôlliker Fuse nucleus, the nucleus raphe pallidus, the dorsal cochlear nucleus, the medial vestibular nucleus, and the nucleus raphe magnus. High levels of PC2 mRNA, but only low to moderate levels of PCl mRNA, were observed in the pontine nuclei, the locus coeruleus, ventral tegmental nucleus, and most motor nuclei of the cranial nerves including the trochlear nucleus, abducens nucleus, facial motor nucleus, and hypoglossal nucleus (Fig. 12). In the nucleus of the solitary tract (NTS), high levels of both $\mathrm{PC} 1$ and $\mathrm{PC} 2$ were present, however, with a different regional distribution (Fig. 12). Whereas $\mathrm{PCl}$ was more abundant in the medial portion, PC2 mRNA was more highly concentrated in the lateral region. Furin mRNA was expressed at low to moderate levels in almost all brainstem nuclei. Higher levels 

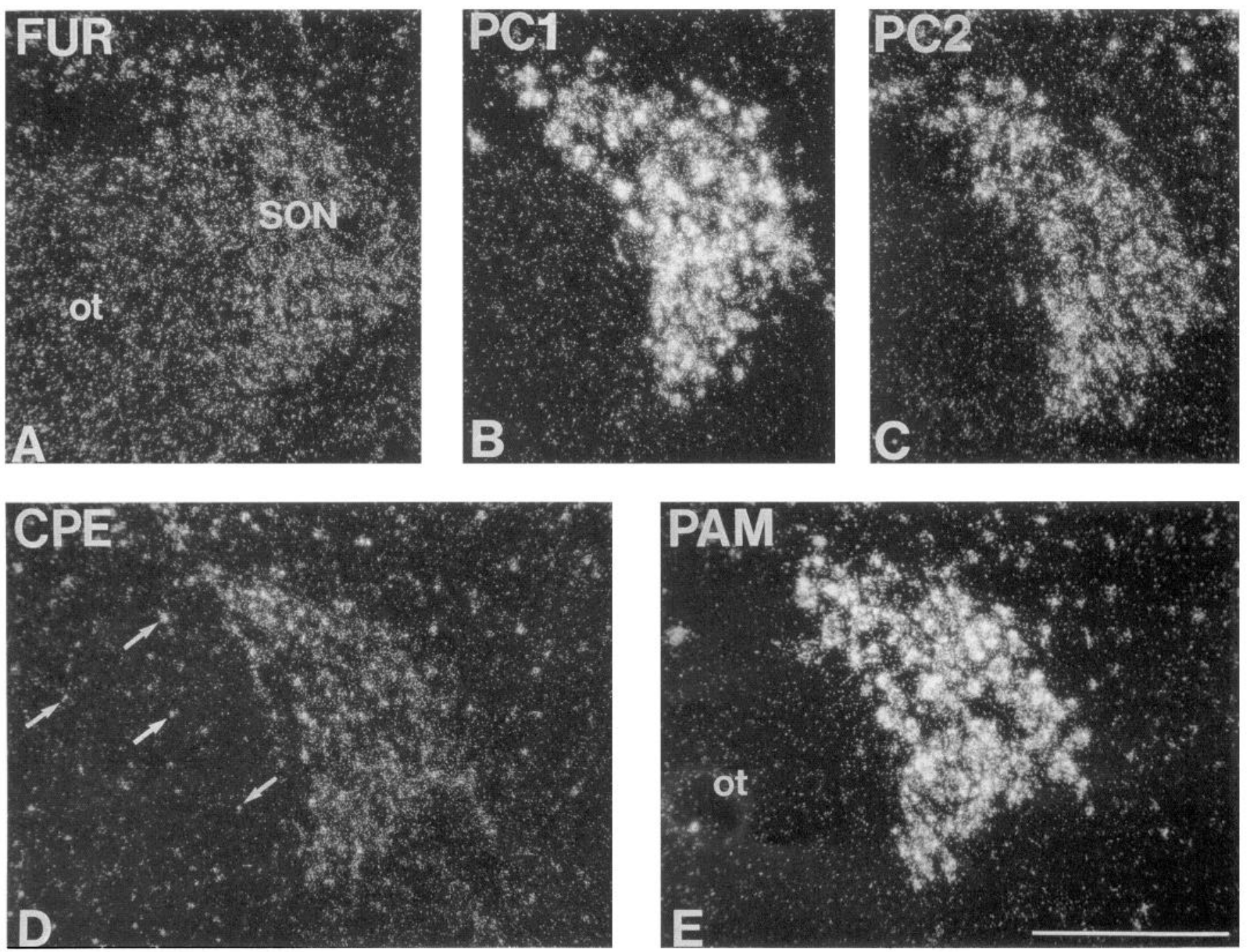

Figure 8. Expression of processing enzymes in the supraoptic nucleus of hypothalamus $(S O N)$. Autoradiograms through the central regions of the supraoptic nucleus demonstrate the presence of all RNA transcripts in the magnocellular neurons. Highest levels of expression were observed for PC1 $(B)$ and PAM $(E)$ mRNAs with moderate to high levels of PC2 $(C)$ and CPE $(D)$ mRNAs. Note the positive hybridization signals over cells in the optic tract $(o t)$ for furin $(A)$ and CPE $(E)$ mRNA (arrows in $D$ ). No signal was observed in the optic tract for PC1, PC2, and PAM. Scale bar, $0.25 \mu \mathrm{m}$.

were observed in the ependyma of the central canal and the area postrema (Fig. 12B). The dorsal motor nucleus of vagus had a reverse ratio of $\mathrm{PC} 1: \mathrm{PC} 2$. The inferior olivary complex, known to produce the C-terminally amidated peptide CRF, had higher levels of PC2 mRNA as compared to PC1.

\section{Cerebellar cortex}

A layer-specific expression pattern was observed in the cerebellar cortex (Fig. 13). The Purkinje cell layer expressed very high levels of furin, PC2, and CPE and moderate levels of PC1. PC2 mRNA was also present over Golgi II cells scattered in the granular cell layer (Fig. 13B), which are known to synthesize proenkephalin (Harlan et al., 1987). In the granular layer low levels of furin and PC2, but not PC1, and moderate levels of CPE mRNA was present. No positive labeling for $\mathrm{PC} 1$ and $\mathrm{PC} 2$ mRNA occurred over the molecular layer (Fig. 13A,B), whereas furin and CPE were expressed at low to moderate levels. No PAM mRNA could be detected in the cerebellar cortex, as previously reported (Schäfer et al., 1992).

\section{Spinal cord}

All enzymes were expressed in the spinal cord, with higher levels in the superficial layers of the dorsal horn and the motor neurons of the anterior horn (see Table 1). PC2 mRNA was expressed at high levels in the superficial layers and in large neurons in the deep layers of the dorsal horn known for the production of opioid peptides, and at very high levels in the large motor neurons of the anterior horn (Fig. 14B). In the ventral horn, PC1 mRNA was expressed at only moderate levels in the large $\alpha$-motor neurons (Fig. 14A). In the superficial dorsal horn, PCl mRNA-positive cells were small and more scattered, with a higher concentration in laminae 1 and 3,4 and 5. No positive signal for either $\mathrm{PC} 1$ or $\mathrm{PC} 2$ was observed in the white matter of the spinal cord. This was in contrast to the distribution of furin and CPE mRNA, which could be observed over cellular elements in both white and gray matter. The distribution of PAM mRNA was strikingly similar to PC2, particularly in the dorsal horn (data not shown). 

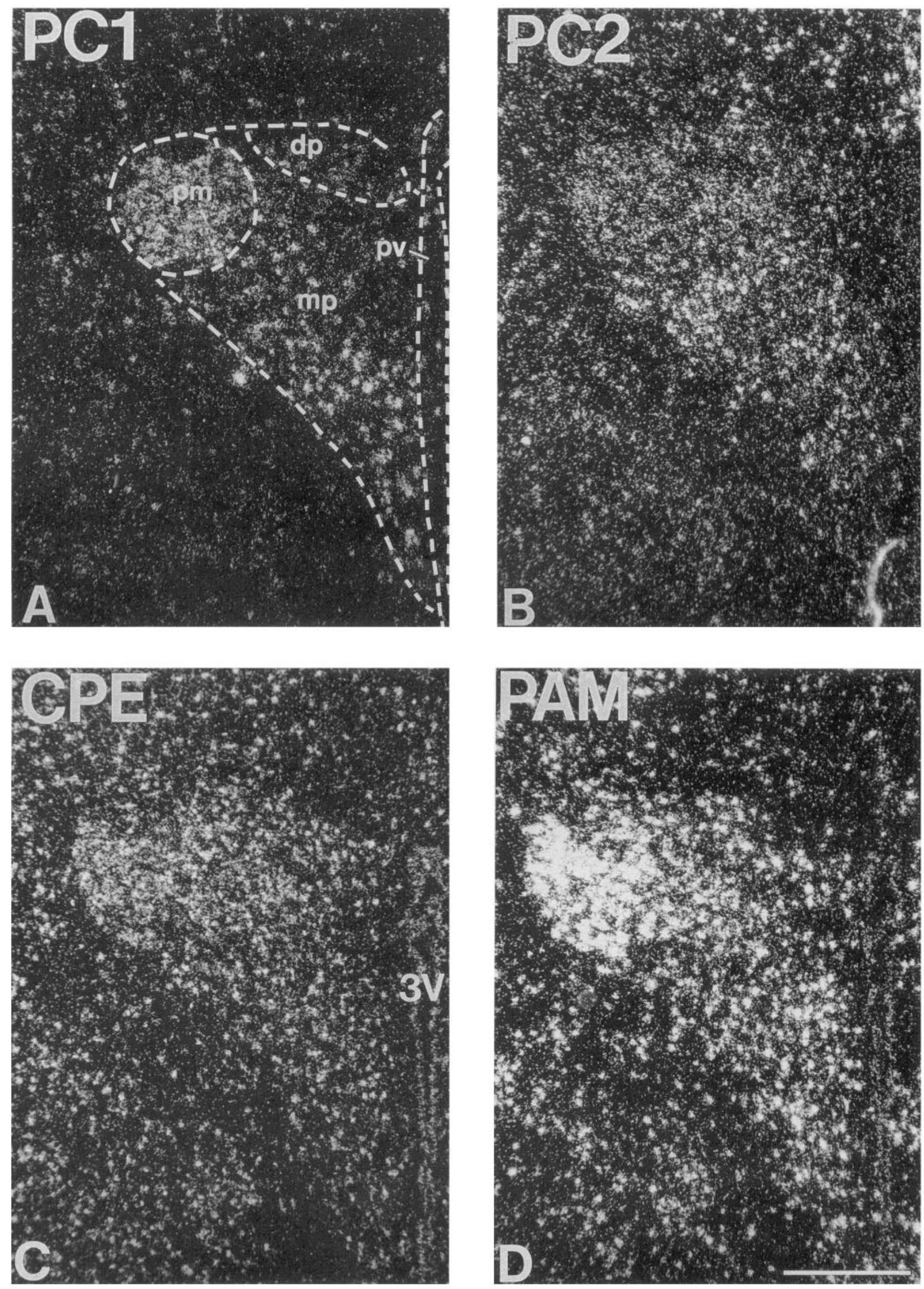

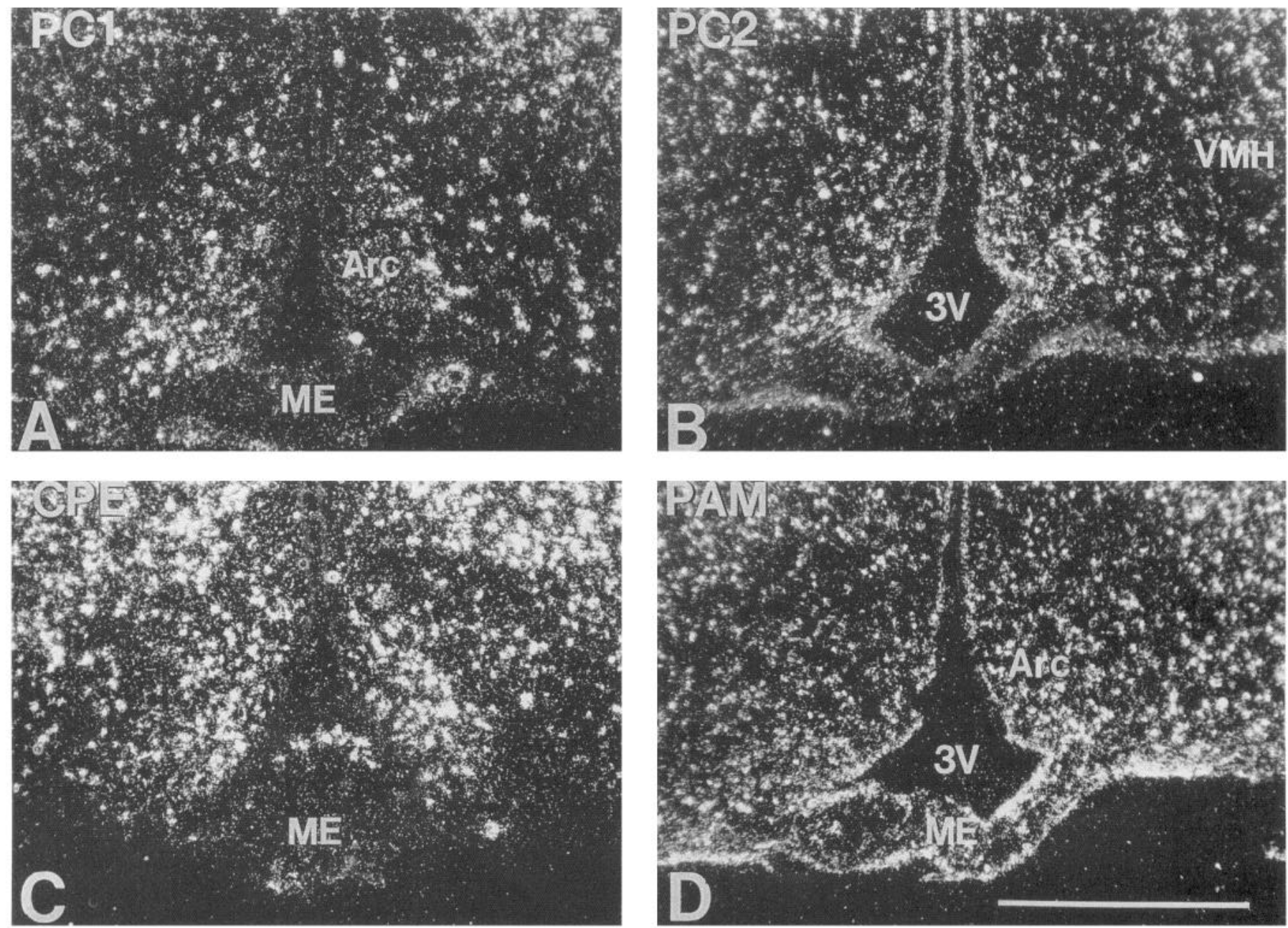

Figure 10. Expression of processing enzymes in the basal hypothalamus. Transcripts coding for either PC1 $(A)$ or PC2 $(B)$ were observed in the arcuate nucleus $(A r C)$ and adjacent areas of the basal hypothalamus. PC2 mRNA was more abundant in the arcuate nucleus proper along the third ventricle $(3 \mathrm{~V})$ where POMC neurons are located. PCl mRNA was more prominent in the adjacent area ventral to the ventromedial hypothalamic nucleus $(V M H)$. All areas contained high levels of CPE mRNA $(C)$ and PAM mRNA $(D)$. Scale bar, $0.25 \mu \mathrm{m}$.

\section{Discussion}

The mRNAs coding for the prohormone processing enzymes furin, $\mathrm{PC} 1$, and $\mathrm{PC} 2$ were localized throughout the rat brain using in situ hybridization histochemistry. Although regional overlaps occurred, each enzyme exhibited a unique expression pattern. The distribution pattern for CPE and PAM mRNAs have previously been described (MacCumber et al., 1990; Schäfer et al., 1992), and our data generally matched that of the literature. The genes coding for the prohormone convertases $\mathrm{PCl}$ and $\mathrm{PC} 2$ are widely expressed often in the same areas, but usually with a distinct distribution pattern, at the subnuclear level. High levels of expression of PC1 and PC2 mRNA were observed in neuropeptide-rich regions such as the hypothalamus, hippocampus, and cerebral cortex. These areas are also characterized by the relatively high expression of CPE and PAM. In general, PC1 mRNA distribution is more restricted, compared to $\mathrm{PC} 2$. An impressive example is the thalamus, where almost all the thalamic nuclei express PC2 mRNA, but PC1 mRNA is found at high levels only in the anterior subdivisions. These unique distribution patterns of $\mathrm{PC} 1$ and $\mathrm{PC} 2$ mRNAs and the observed differences in their relative ratios of expression at the cellular level suggest distinct roles in the activation of brain proproteins. This variation in cellular mRNA levels may have significance for region-specific posttranslational processing. In other words, the same substrate proneuropeptide may well result in different biologically active end products depending on the ratio of $\mathrm{PC} 1: \mathrm{PC} 2$ expression. This notion has already been demonstrated to be valid in understanding the differential posttranslational processing of pituitary POMC, which occurs

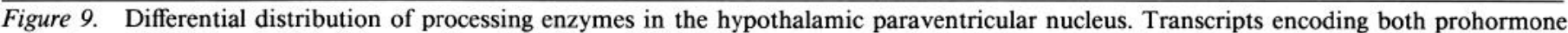

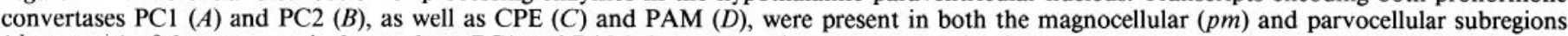

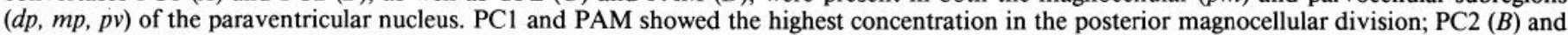

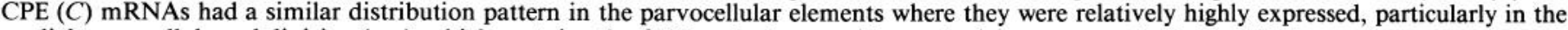
medial parvocellular subdivision $(\mathrm{mp})$, which contains the CRF and other peptide-synthesizing neurons. Scale bar, $0.25 \mu \mathrm{m}$. 

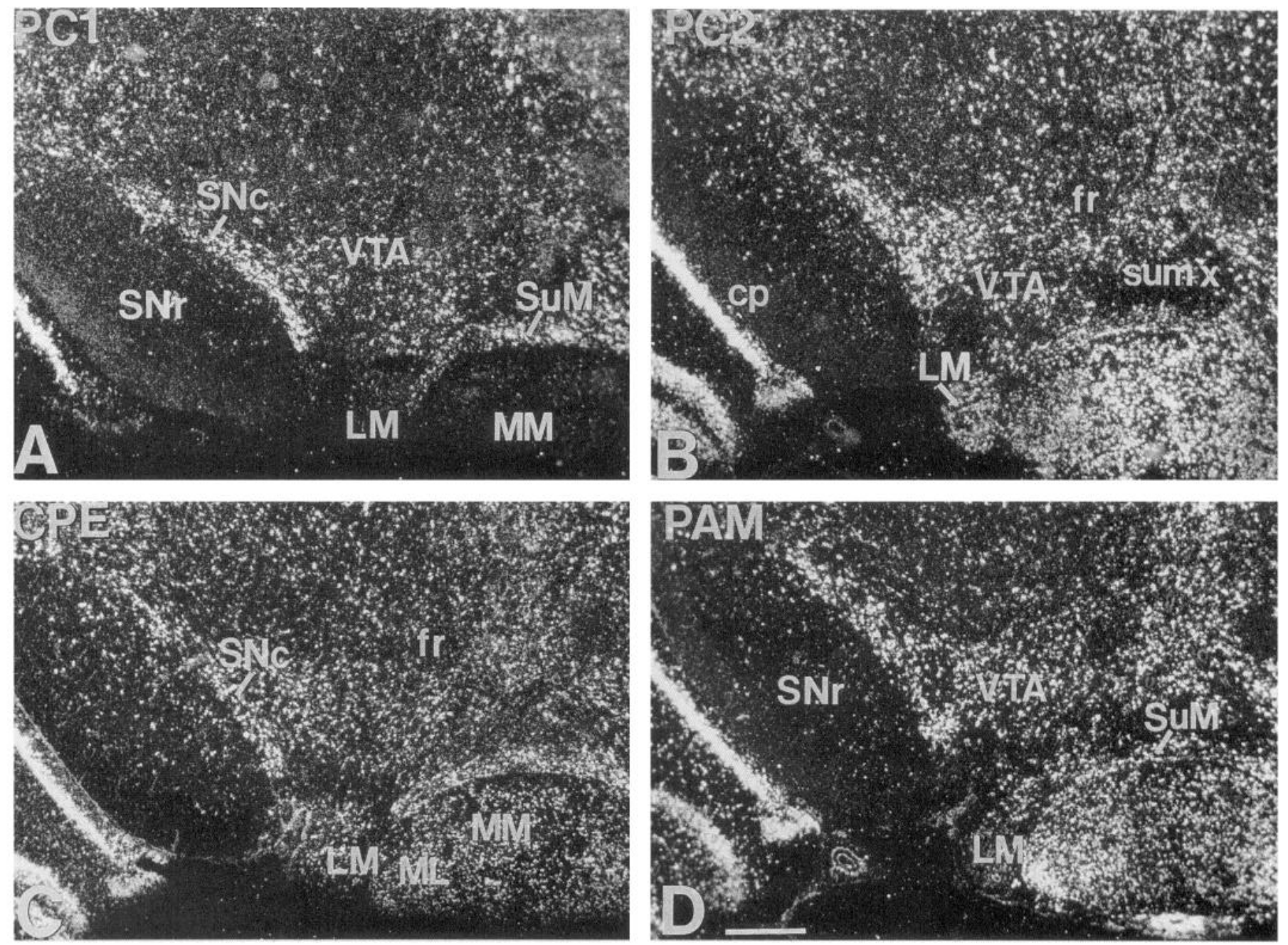

Figure 11. Expression of processing enzymes in the region of the substantia nigra. The neuropeptide-rich substantia nigra expressed moderate to high levels of PC1 mRNA $(A)$ and high levels of PC2 mRNA $(B)$, particularly in the pars compacta $(S N C)$, where CPE $(C)$ and PAM $(D)$ mRNAs were also present at moderate to high levels. In the pars reticulata, PC2 mRNA $(B)$ was more abundant than PC1 mRNA $(A)$. In the mammillary body, a striking heterogeneity of processing enzyme distribution was observed. $\mathrm{PCl} \mathrm{mRNA}(A)$ was present only in the supramammillary nucleus $(\mathrm{SuM})$, where with CPE and PAM transcripts were also expressed. In contrast, PC2 mRNA was expressed at high levels in the medial mammillary nucleus $(M M)$, and at moderate levels in the lateral mammillary nucleus. While CPE mRNA was present at moderate levels in all subregions of the mammillary body $(C)$, PAM mRNA distribution was quite heterogeneous, with the highest levels in the lateral part of the medial mammillary nucleus, and lowest levels in the lateral mammillary nucleus. Scale bar, $0.5 \mu \mathrm{m}$.

in the anterior lobe corticotrophs and the intermediate lobe melanotrophs (Day et al., 1992; Benjannet et al., 1991). In the corticotroph, POMC is processed mostly into ACTH and $\beta$-lipotropin, and these cells express higher levels of $\mathrm{PC} 1$ than PC2 mRNA. In the intermediate lobe, POMC is processed mainly to $\alpha$-MSH and $\beta$-endorphin, and these cells express higher levels of PC2 than PC1 mRNA (Day et al., 1992). Furthermore, the mRNA distribution of these pituitary convertases, as well as the POMC tissue-specific end products correspond to the now known cleavage specificity of $\mathrm{PC} 1$ and $\mathrm{PC} 2$ for the POMC precursor (Benjannet et al., 1991; Thomas et al., 1991). A similar scenario could be envisioned for the processing of specific precursors in the CNS. For example, the POMC gene is expressed in the brain in two nuclei, the hypothalamic arcuate nucleus and in the caudal NTS in the brainstem (Gee et al., 1983; Bronstein et al., in press). A differential posttranslational processing pattern in both these regions has been reported. In the present study, we have observed the expression of PC1 and PC2 in both regions (see Figs. 10, 12). Precise colocalization studies will be needed in order to establish the exact relationship of POMC and $\mathrm{PC} 1$ or PC2 mRNAs in the arcuate and NTS neurons. Furthermore, similarities in distribution patterns of neuropeptides and convertases can point to potential precursor selectivity for each convertase. For example, the expression of cholecystokinin in the neocortex and the thalamus closely resembles the distribution pattern of PC2. Other possible precursor substrates for PC2 could be proenkephalin, which shows a similar distribution pattern in the caudate-putamen, and calcitonin generelated peptide, which is synthesized in the motor neurons of spinal cord, where PC2 is highly expressed. However, the situation in the brain is further complicated by the complex and multiple coexistence of several neuropeptides in the same neuron is the rule rather than the exception. For example, magnocellular hypothalamic neurons in the paraventricular and supraoptic hypothalamic nuclei produce almost all of the neuropeptides present in hypothalamus. Therefore, it can be 

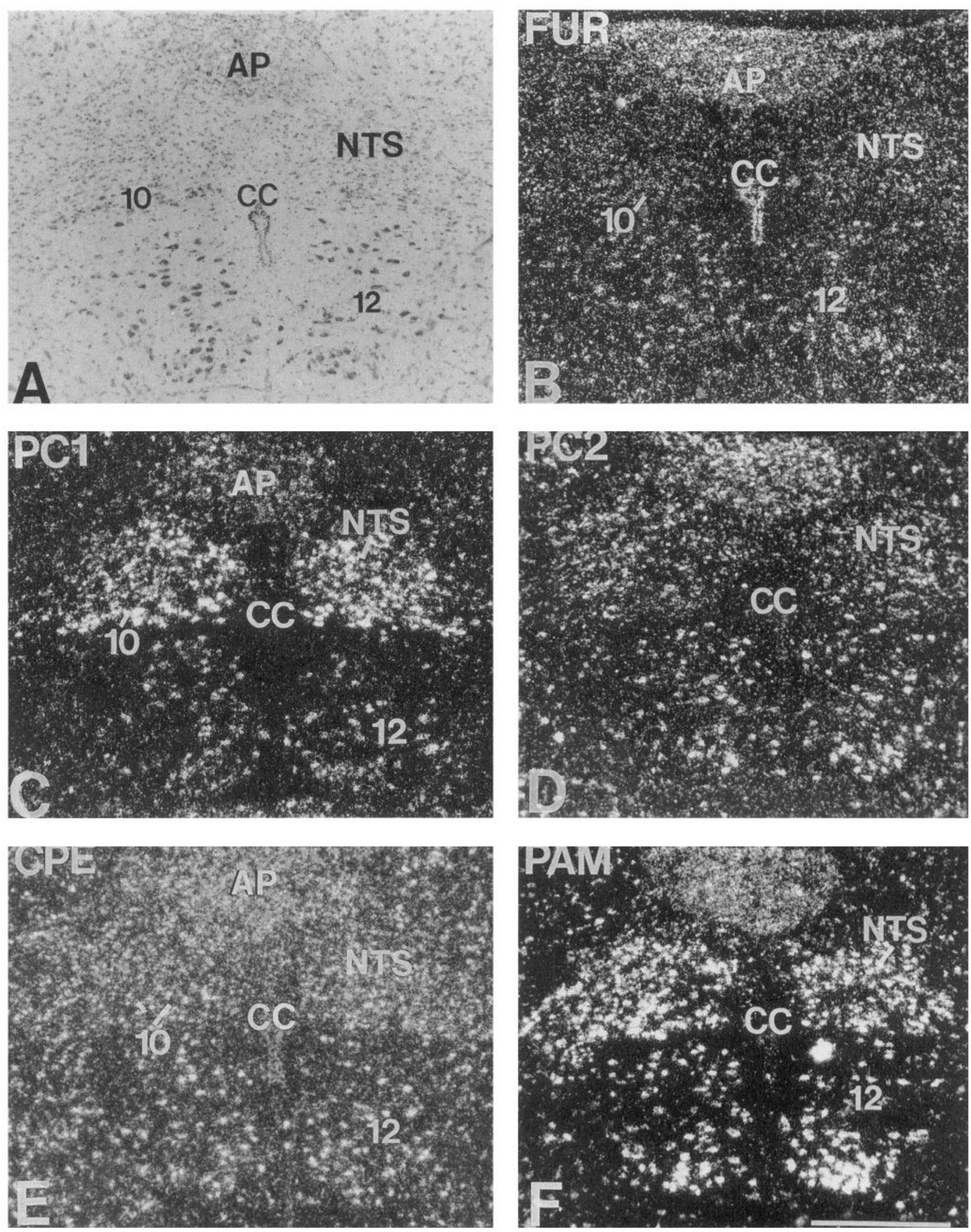

Figure 12. Localization of processing enzyme mRNAs in the caudal brainstem. For identification of cellular structures an adjacent section $(A)$ was counterstained with cresyl violet. High levels of furin mRNA $(B)$ were observed in the area postrema, where all other processing enzymes were also present, and in the ependymal cells of the central canal. PC1 mRNA $(C)$ was abundant in the NTS and the dorsal motor nucleus of vagus, and to a lesser extent in the hypoglossal nucleus. Highest levels of PC2 mRNA $(D)$ expression were seen in the ventrolateral region of the NTS and the hypoglossal nucleus. Expression in the dorsal motor nucleus of the vagus was weak in comparison to PCl mRNA $(C)$. CPE mRNA $(E)$ was present in all regions. PAM mRNA $(F)$ was highly expressed in all regions mentioned above. Scale bar, $0.5 \mu \mathrm{m}$. 

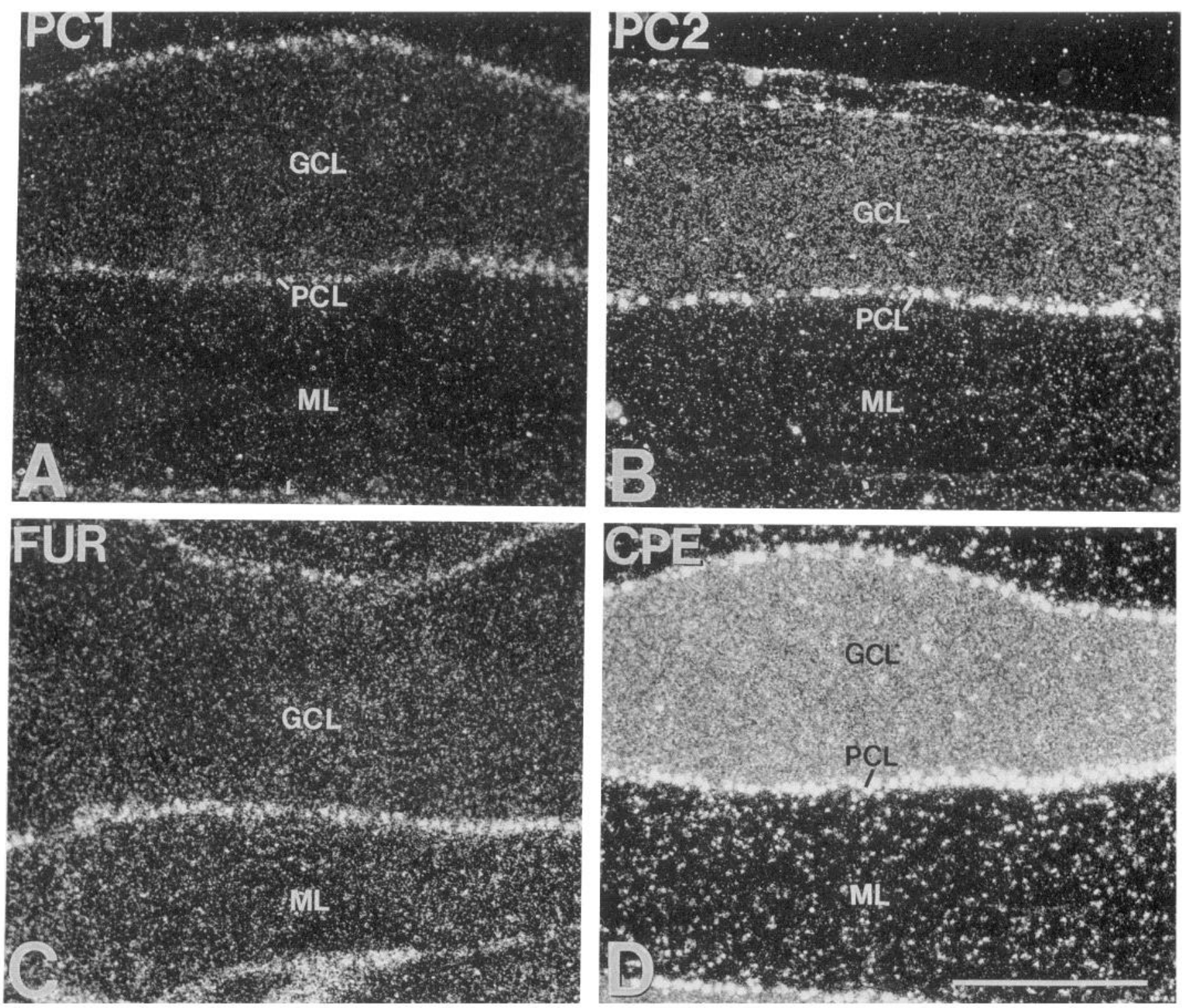

Figure 13. Expression of prohormone convertases in the cerebellar cortex. $A$, Expression of $\mathrm{PCl} \mathrm{mRNA}$ is highly restricted to the Purkinje cell layer $(P C L)$. No labeling was observed over the molecular cell layer $(M L)$. B, PC2 mRNA showed very high levels in the $P C L$ and low levels in the granular cell layer $(G C L)$, although some scattered cells in the $G C L$ showed high expression levels. $C$, Furin mRNA was highly abundant in the PCL but also present at moderate levels in the $G C L$ and $M L . D, C P E$ mRNA showed high expression levels in all layers. PAM mRNA was undetectable as previously described. Scale bar, $0.5 \mu \mathrm{m}$.

misleading to pinpoint one specific neuropeptide precursor as substrate for a particular convertase even after their coexistence has been demonstrated. Another level of complexity is added since the convertases may also be involved in functions other than processing proneuropeptides such as the activation of other enzymes involved in cellular biosynthetic activity. For example, the protein precursor for PAM contains pairs of basic amino acids that require cleavage in order to release the various activities related to amidation (Eipper et al., 1987). Interestingly, whenever CPE or PAM were highly expressed in a region, at least one of the three endoproteases was also highly expressed. The convertases themselves need to be cleaved to acquire activity. Besides autoactivation of PC1 and PC2, it has been hypothesized that another enzyme such as furin may be responsible for activation. The ubiquitous distribution pattern of furin may support this hypothesis. However, the findings of the present study also suggest other functions of furin. The presence of furin mRNA in non-neuronal cells such as the choroid plexus and ependymal cells, cells lacking in dense core secretory granules, points to a possible role of furin as a convertase processing proproteins in the constitutive secretory pathway. In the ependymal cells of the lateral ventricle, where PAM is also expressed, furin is most likely the convertase responsible for the initial cleavage step for the generation of a yet unidentified peptide(s), which may be amidated. Furthermore, in vitro studies have shown that furin may be involved in the processing of a variety of blood coagulation factors and growth factors (Bresnahan et al., 1990; Wise et al., 1990; Misumi et al., 1991). The localization of furin mRNA in the cellular elements lacking the bloodbrain barrier such as the circumventricular organs and the ventricular ependyma is certainly consistent with these results. In fact, the precursor of complement $\mathrm{C} 3$, which has recently been 

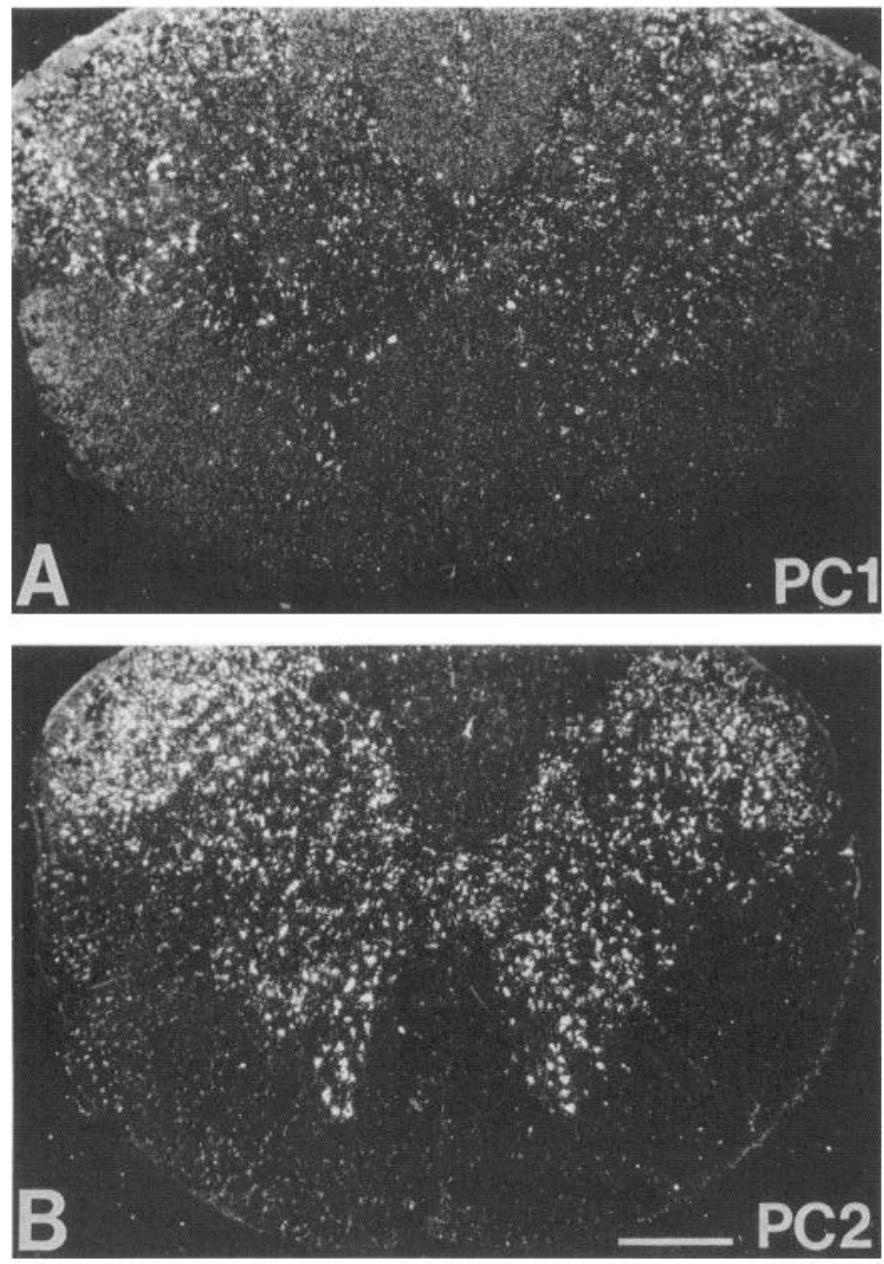

Figure 14. Differential expression of prohormone convertases in the spinal cord. Transcript levels of both PC1 mRNA $(A)$ and PC2 mRNA $(B)$ are particularly abundant in the neuropeptide-rich regions of the dorsal horn, where their distributions are overlapping. In the anterior horn, PC2 mRNA is severalfold more abundant than PC1 and localized in large cells, identified as motor neurons in adjacent Nissl stains (data not shown). Scale bar, $0.5 \mu \mathrm{m}$.

shown to be processed by furin (Misumi et al., 1991), is expressed by cells that are located in these regions of high furin expression (M.K.-H. Schäfer, unpublished observation). The high abundance of furin mRNA in the islands of Calleja, whose function is still unresolved, suggests that it is a region of high posttranslational processing activity.

The identification of specific combinations of processing enzymes in different brain regions suggests that specific enzymatic pathways are involved in precursor processing. For example, in the choroid plexus or in ependyma of the lateral ventricle, amidated peptides are likely generated by using furin as the precursor cleaving enzyme, since $\mathrm{PC} 1$ and $\mathrm{PC} 2$ are lacking. In the Edinger-Westphal nucleus, production of amidated peptides may be achieved by prior cleavage of the precursor by $\mathrm{PCl}$, since no PC2 is expressed. Whether these specific combinations of processing enzymes are responsible for region-specific differences in posttranslational processing awaits further study. While the expression of at least one of the three subtilisin-like mammalian proteinases has been demonstrated together with CPE and PAM in all brain regions studied, it is more than likely that given the richness and complexity of the nervous system, other members of this family may yet be discovered in the CNS.

\section{Appendix}

Abbreviations

$\begin{array}{ll}10 & \text { Dorsal motor nucleus vagus } \\ 12 & \text { Hypoglossal nucleus } \\ 3 \mathrm{~V} & \text { Third ventricle } \\ 4 \mathrm{~V} & \text { Fourth ventricle } \\ \text { ac } & \text { Anterior commissure } \\ \text { Acb } & \text { Accumbens nucleus } \\ \text { AD } & \text { Anterodorsal thalamic nucleus } \\ \text { AH } & \text { Anterior hypothalamic area } \\ \text { AM } & \text { Anteromedial thalamic nucleus } \\ \text { AON } & \text { Anterior olfactory nucleus } \\ \text { AP } & \text { Area postrema } \\ \text { Aq } & \text { Aqueduct } \\ \text { Arc } & \text { Arcuate hypothalamic nucleus } \\ \text { BL } & \text { Basolateral nucleus of amygdal }\end{array}$

CA1 Field CA1 of Ammon's horn

CA2 Field CA2 of Ammon's horn

CA3 Field CA3 of Ammon's horn

CBL Cerebellum

cc, CC Central canal

CG Central gray

ch pl, Ch Pl Choroid plexus

cp Cerebral peduncle

$\mathrm{CPu} \quad$ Caudate-putamen

CTX Neocortex

D3V

DEn

DG

DLG

DM

dp

DR

DTg

ep

EP1

f

fi

fr

Gl

GP

HI

ic, IC

ICj

InG

ION

LDVL

LH

LHbL

LHbM

LM

LPB

LV

$\mathrm{Me}$

ME

MGD

MGV

$\mathrm{MHb}$

Mi

$\mathrm{ml}$

ML

MM

$\mathrm{mp}$

MPB

NTS

ot

ox

$\mathrm{PH}$

Pir
Dorsal third ventricle

Dorsal endopiriform nucleus

Dentate gyrus

Dorsal lateral geniculate nucleus

Dorsomedial hypothalamic nucleus

Dorsal parvocellular division, paraventricular hypothalamic nucleus

Dorsal raphe nucleus

Dorsal tegmental nucleus

Ependyma

External plexiform layer of the olfactory bulb

Fornix

Fimbria of the hippocampus

Fasciculus retroflexus

Glomerular layer of the olfactory bulb

Globus pallidus

Hippocampal formation

Internal capsule

Islands of Calleja

Intermediate gray layer of the superior colliculus

Inferior olivary nucleus

Laterodorsal thalamic nucleus, ventrolateral division

Lateral hypothalamic area

Lateral habenular nucleus, lateral division

Lateral habenular nucleus, medial division

Lateral mammillary nucleus

Lateral parabrachial nucleus

Lateral ventricle

Medial nucleus of amygdala

Median eminence

Medial geniculate nucleus, dorsal division

Medial geniculate nucleus, ventral division

Medial habenular nucleus

Medial lemniscus

Medial mammillary nucleus, lateral division

Medial mammillary nucleus, medial division

Mammillary peduncle

Medial parabrachial nucleus

Nucleus of the solitary tract

Optic tract

Optic chiasm

Posterior hypothalamic area

Piriform cortex
Mitral cell layer of the olfactory bulb 


\begin{tabular}{|c|c|}
\hline $\mathrm{pm}$ & $\begin{array}{l}\text { Posterior magnocellular division, paraventricular hypo- } \\
\text { thalamic nucleus }\end{array}$ \\
\hline PnC & Pontine reticular nucleus, caudal division \\
\hline $\mathrm{PO}$ & Posterior thalamic nuclear group \\
\hline pv & Periventricular hypothalamic nucleus \\
\hline PVA & Paraventricular thalamic nucleus, anterior division \\
\hline PVN & Paraventricular hypothalamic nucleus \\
\hline PVP & Paraventricular thalamic nucleus, posterior division \\
\hline py & Pyramidal tract \\
\hline $\mathrm{Re}$ & Reuniens thalamic nucleus \\
\hline RLi & Rostral linear nucleus of the raphe \\
\hline RN & Red nucleus \\
\hline Sch & Suprachiasmatic nucleus \\
\hline SFO & Subfornical organ \\
\hline SG & Suprageniculate thalamic nucleus \\
\hline SNc & Substantia nigra, pars compacta \\
\hline $\mathrm{SNr}$ & Substantia nigra, pars reticulata \\
\hline SON & Supraoptic hypothalamic nucleus \\
\hline SR5 & Spinal trigeminal nucleus \\
\hline STh & Subthalamic nucleus \\
\hline SuG & Superficial gray layer of the superior colliculus \\
\hline SuM & Supramammillary nucleus \\
\hline sum $\mathrm{x}$ & Supramammillary decussation \\
\hline TT & Tenia tecta \\
\hline Tu & Olfactory tubercle \\
\hline VL & Ventrolateral thalamic nucleus \\
\hline VM & Ventromedial thalamic nucleus \\
\hline VMH & Ventromedial hypothalamic nucleus \\
\hline VPL & Ventral posterolateral thalamic nucleus \\
\hline VPM & Ventral posteromedial thalamic nucleus \\
\hline VTA & Ventral tegmental area \\
\hline
\end{tabular}

\section{References}

Antoni FA, Palkovits M, Makara GB, Linton EA, Lowry PJ, Kiss JZ (1983) Immunoreactive corticotropin-releasing hormone (CRF) in the hypothalamo-infundibular tract. Neuroendocrinology 36:415-432.

Barr PJ, Mason OB, Landsberg KE, Wong PA, Kiefer MC, Brake AJ (1991) cDNA and gene structure for a human subtilisin-like protease with cleavage specificity for paired basic amino acid residues. DNA Cell Biol 10:319-328.

Benjannet S, Rondeau N, Day R, Chrétien M, Seidah NG (1991) PCl and $\mathrm{PC} 2$ are proprotein convertases capable of cleaving proopiomelanocortin at distinct pairs of basic residues. Proc Natl Acad Sci USA 88:3564-3568.

Benjannet S, Rudelhuber T, Mercure C, Rondeau N, Chrétien M, Seidah NG (1992) Pro-protein conversion is determined by a multiplicity of factors including convertase processing, substrate specificity and intracellular environment: cell type-specific processing of human prorenin by the convertase PCl. J Biol Chem 267:11417-11423.

Birch NP, Tracer HL, Hakes DJ, Loh YP (1991) Coordinate regulation of mRNA levels of pro-opiomelanocortin and the candidate processing enzymes $\mathrm{PC} 2$ and $\mathrm{PC} 3$, but not furin, in rat pituitary intermediate lobe. Biochem Biophys Res Commun 179:1311-1319.

Bloomquist BT, Fipper BA, Mains RE (1991) Prohormone-converting enzymes: regulation and evaluation of function using antisense RNA. Mol Endocrinol 9:2014-2024.

Bolam JP, Wainer BH, Smith AD (1984) Characterization of cholinergic neurons in the rat neostriatum. A combination of choline acetyltransferase immunocytochemistry, Golgi impregnation, and electron microscopy. Neuroscience 12:711-718.

Bondy CA, Whitnall MH, Brady LS (1989) Regulation of carboxypeptidase $\mathrm{H}$ gene expression in magnocellular neurons: response to osmotic stimulation. Mol Endocrinol 3:2086-2092.

Braas KM, Stoffers DA, Eipper BA, May V (1989) Tissue specific expression of rat peptidylglycine alpha-amidating monooxygenase activity and mRNA. Mol Endocrinol 3:1387-1398.

Bresnahan PA, Leduc R, Thomas L, Thomer J, Gibson HL, Brake AJ, Barr PJ, Thomas G (1990) Human fur gene encodes a yeast KEX2like endoprotease that cleaves pro-beta-NGF in vivo. J Cell Biol 111: 2851-2859.

Bronstein DM, Schäfer MKH, Watson SJ, AKil H (1992) Evidence that $\beta$-endorphin is synthesized in cells in the nucleus tractus solitarius: detection of POMC mRNA. Brain Res 587:269-275.

Burgunder JM, Young WS III (1989) Neurokinin B and substance P genes are co-expressed in a subset of neurons in the rat habenula. Neuropeptides 13:165-169.

Day R, Schäfer MK-H, Watson SJ, Chrétien M, Seidah NG (1992) Distribution and regulation of the prohormone convertases $\mathrm{PCl}$ and PC2 in the rat pituitary. Mol Endocrinol 6:485-497.

Docherty K, Steiner DF (1982) Post-translational proteolysis in polypeptide hormone biosynthesis. Annu Rev Physiol 44:625-638.

Eipper BA, Park LP, Dickerson IM, Keutmann HT, Thiele EA, Rodriguez $\mathrm{H}$, Schofield PR, Mains RE (1987) Structure of the precursor to an enzyme mediating COOH-terminal amidation in peptide biosynthesis. Mol Endocrinol 1:777-790.

Foster DC, Holly RD, Sprecher CA, Walker KM, Kumar AA (1991) Endoproteolytic processing of the human protein $C$ precursor by the yeast Kex 2 endopeptidase coexpressed in mammalian cells. Biochemistry 30:367-372.

Fricker LD, Adelman JP, Douglass J, Thompson RC, Von SR, Hutton $\mathrm{J}$ (1989) Isolation and sequence analysis of cDNA for rat carboxypeptidase E [EC 3.4.17.10], a neuropeptide processing enzyme. Mol Endocrinol 3:666-673.

Fricker LD, Reaves BJ, Das B, Dannies PS (1990a) Comparison of the regulation of carboxypeptidase $\mathrm{E}$ and prolactin in $\mathrm{GH} 4 \mathrm{Cl}$ cells, a rat pituitary cell line. Neuroendocrinology 51:658-663.

Fricker LD, Das B, Angeletti RH (1990b) Identification of the pHdependent membrane anchor of carboxypeptidase $\mathrm{E}$ (EC 3.4.17.10). J Biol Chem 265:2476-2482.

Fuller RS, Brake A, Thorner J (1989) Yeast prohormone processing enzyme (KEX2 gene product) is a $\mathrm{Ca}^{2+}$-dependent serine protease. Proc Natl Acad Sci USA 86:1434-1438.

Gee C, Chen CLC, Roberts J, Thompson R, Watson SJ (1983) Identification of pro-opiomelanocortin neurons in rat hypothalamus by in situ cDNA-mRNA hybridization. Nature 306:374-376.

Grimwood BG, Plummer TJ, Tarentino AL (1989) Carboxypeptidase $H$. A regulatory peptide-processing enzyme produced by human hepatoma Hep G2 cells. J Biol Chem 264:15662-15667.

Harlan RE, Shivers BD, Romano GJ, Howells RD, Pfaff DW (1987) Localization of preproenkephalin mRNA in the rat brain and spinal cord by in situ hybridization. J Comp Neurol 258:159-184.

Hatsuzawa K, Hosaka M, Nakagawa T, Nagase M, Shoda A, Murakami K, Nakayama K (1990) Structure and expression of mouse furin, a yeast Kex2-related protease. Lack of processing of coexpressed prorenin in GH4C1 cells. J Biol Chem 265:22075-22078.

Heimer L, Alheid GF, Zaborsky L (1985) Basal ganglia. In: The rat nervous system, Vol 1 (Paxinos G, ed), pp 37-86. Marrickville, Australia: Academic.

Hook VY, Affolter HU, Palkovits M (1990) Carboxypeptidase H in the hypothalamo-neurohypophysial system: evidence for processing and activation of a prohormone-processing enzyme during axonal transport. J Neurosci 10:3219-3226.

Ingram SM, Krause RG 2nd, Baldino F Jr, Skeen LC, Lewis ME (1989) Neuronal localization of cholecystokinin mRNA in the rat brain by using in situ hybridization histochemistry. J Comp Neurol 287:260272.

MacCumber MW, Snyder SH, Ross CA (1990) Carboxypeptidase E (enkephalin convertase): mRNA distribution in rat brain by in situ hybridization. I Neurosci 10:2850-2860.

Mahata SK, Mahata M, Marksteiner J, Sperk G, Fischer-Colbrie R, Winkler H (1991) Distribution of mRNAs for chromogranins A and $B$ and secretogranin II in rat brain. Eur $\mathrm{J}$ Neurosci 3:895-904.

Misumi Y, Oda K, Fujiwara T, Takami N, Tashiro K, Ikehara Y (1991) Functional expression of furin demonstrating its intracellular localization and endoprotease activity for processing of proalbumin and complement pro-C3. J Biol Chem 266:16954-16959.

Mizuno K, Nakamura T, Ohshima T, Tanaka S, Matsuo H (1989) Characterization of KEX2-encoded endopeptidase from yeast Saccharomyces cerevisiae. Biochem Biophys Res Commun 159:305-311.

Ouafik L, May V, Keutmann HT, Eipper BA (1989) Developmental regulation of peptidylglycine alpha-amidating monooxygenase (PAM) in rat heart atrium and ventricle. Tissue-specific changes in distribution of PAM activity, mRNA levels, and protein forms. J Biol Chem 264:5839-5845.

Roebroek AJM, Schalken JA, Leunissen JAM, Onnekink C, Gloemers HPJ, Van de Ven WJM (1986) Evolutionary conserved close linkage of $\mathrm{c}$-fes/fps proto-oncogene and genetic sequences encoding a receptor-like protein. EMBO J 5:2197-2202.

Schäfer MKH, Stofers DA, Eipper BA, Watson SJ (1992) Expression 
of peptidylglycine $\alpha$-amidating monooxygenase (EC1.14.17.3) in the rat central nervous system. J Neurosci 12:222-234.

Schalken JA, Roebroek AJM, Oomen PPCA, Wagenaar SS, Debryne FMJ, Bloemers HPJ, Van de Ven WJM (1987) fur gene expression as discriminate marker for small cell and non small cell lung carcinomas. J Clin Invest 80:1545-1549.

Seidah NG, Gaspar L, Mion P, Marcinkiewicz M, Mbikay M, Chrétien M (1990) cDNA sequence of two distinct pituitary proteins homologous to Kex2 and furin gene products: tissue-specific mRNAs encoding candidates for pro-hormone processing proteinases. DNA Cell Biol 9:415-424.

Seidah NG, Marcinkiewicz M, Benjannet S, Gaspar L, Beaubien G, Mattei MG, Lazure C, Mbikay M, Chrétien M (1991) Cloning and primary sequence of a mouse candidate prohormone convertase $\mathrm{PCl}$ homologous to PC2, furin, and Kex2: distinct chromosomal localization and messenger RNA distribution in brain and pituitary compared to PC2. Mol Endocrinol 5:111-122.

Seidah NG, Day R, Hamelin J, Gaspar A, Collard MW, Chrétien M (1992) Testicular expression of PC4 in the rat: molecular diversity of a novel germ cell-specific KEX2/subtilisin-like pro-protein convertase. Mol Endocrinol 6:1559-1569.

Seidah NG, Day R, Marcinkiewicz M, Chrétien M (in press) Mammalian paired basic amino acids convertases of prohormones and proproteins. Ann NY Acad Sci, in press.

Smeekens SP, Steiner DF (1990) Identification of a human insulinoma cDNA encoding a novel mammalian protein structurally related to the yeast dibasic processing protease Kex2. J Biol Chem 265:29973000 .

Smeekens SP, Avruch AS, LaMendola J, Chan SJ, Steiner DF (1991) Identification of a cDNA encoding a second putative prohormone convertase related to PC2 in AtT20 cells and islets of Langerhans. Proc Natl Acad Sci USA 88:340-344.

Thiele EA, Marek KL, Eipper BA (1989) Tissue-specific regulation of peptidyl-glycine alpha-amidating monooxygenase expression. Endocrinology 125:2279-2288.

Thomas G, Thorne BA, Thomas L, Allen RG, Hruby DE, Fuller R, Thorner J (1988) Yeast KEX2 endopeptidase correctly cleaves a neuroendocrine prohormone in mammalian cells. Science 241:226230.

Thomas L, Cooper A, Bussey H, Thomas G (1990) Yeast KEX1 protease cleaves a prohormone processing intermediate in mammalian cells. J Biol Chem 265:10821-10824.

Thomas L, Leduc R, Thorne BA, Smeekens SP, Steiner DF, Thomas G (1991) Kex2-like endoproteases PC2 and PC3 accurately cleave a model prohormone in mammalian cells: evidence for a common core of neuroendocrine processing enzymes. Proc Natl Acad Sci USA 88:5297-5301.

Van de Ven WJM, Voorberg J, Fontijn R, Pannekoek H, Van den Ouweland AMW, Van Duijnhoven HLP, Roebroek AJM, Siezen RJ (1990) furin is a subtilisin-like proprotein processing enzyme in higher eukaryotes. Mol Biol Rep 14:265-275.

Van den Ouweland AMW, Van Groningen JJM, Roebroek AJM, Onnekink C, Van de Ven WJM (1990) Nucleotide sequence analysis of the human fur gene. Nucleic Acids Res 17:7101-7102.

Vilijn MH, Das B, Kessler JA, Fricker LD (1989) Cultured astrocytes and neurons synthesize and secrete carboxypeptidase $E$, a neuropeptide-processing enzyme. J Neurochem 53:1487-1493.

Wise RJ, Barr PJ, Wong PA, Kiefer MC, Brake AJ, Kaufman RJ (1990) Expression of a human proprotein processing enzyme: correct cleavage of the von Willebrand factor precursor at a paired basic amino acid site. Proc Natl Acad Sci USA 87:9378-9382.

Zollinger L, Racine C, Crine P, Boileau G, Germain D, Thomas DY, Gossard F (1990) Intracellular proteolytic processing of proopiomelanocortin in heterologous COS-1 cells by the yeast KEX2. Biochem Cell Biol 68:635-640. 